\title{
Revisiting wintertime cold air intrusions at the east of the Andes: propagating features from subtropical Argentina to Peruvian Amazon and relationship with large-scale circulation patterns
}

\author{
Jhan Carlo Espinoza • Josyane Ronchail • Matthieu Lengaigne • \\ Nelson Quispe · Yamina Silva • Maria Laura Bettolli • \\ Grinia Avalos • Alan Llacza
}

Received: 2 July 2012/ Accepted: 15 December 2012

(C) Springer-Verlag Berlin Heidelberg 2012

\begin{abstract}
This study investigates the spatial and temporal characteristics of cold surges that propagates northward along the eastern flank of the Andes from subtropical to tropical South America analysing wintertime in situ daily minimum temperature observations from Argentina, Bolivia and Peru and ERA-40 reanalysis over the 1975-2001 period. Cold surges usually last 2 or 3 days but are generally less persistent in the southern La Plata basin compared to tropical regions. On average, three to four cold surges are reported each year. Our analysis reveals that $52 \%$ of cold episodes registered in the south of La Plata basin propagate northward to the northern Peruvian Amazon at a speed of around $20 \mathrm{~m} \mathrm{~s}^{-1}$. In comparison to cold surges that do not reach the tropical region, we demonstrate that these cold surges are characterized, before they reach the tropical region, by a higher occurrence of a specific
\end{abstract}

J. C. Espinoza $(\bowtie) \cdot$ Y. Silva

Instituto Geofísico del Perú (IGP), Calle Badajoz 169 Mayorazgo, Ate., Lima 03, Peru

e-mail: Jhan-carlo.espinoza@igp.gob.pe

J. Ronchail

Sorbonne Paris Cité and Laboratoire d'Océanographie et de Climat: Expérimentation et Approches Numériques (LOCEAN), Univ Paris Diderot, Paris, France

M. Lengaigne

Institut de Recherche pour le Développement (IRD)

and LOCEAN, Paris, France

N. Quispe · G. Avalos · A. Llacza

Servicio Nacional de Meteorología e Hidrología (SENAMHI), Lima, Peru

M. L. Bettolli

Departamento de Ciencias de la Atmósfera y los Océanos (FCEN), Universidad de Buenos Aires, Buenos Aires, Argentina circulation pattern associated to southern low-level winds progression toward low latitudes combined with subsidence and dry condition in the middle and low troposphere that reinforce the cold episode through a radiative effect. Finally, the relationship between cold surges and atmosphere dynamics is illustrated for the two most severe cold intrusions that reached the Peruvian and Bolivian Amazon in the last 20 years.

Keywords Peruvian Amazon - Bolivian Amazon ·

Argentina $\cdot$ Cold surges $\cdot$ Low-level winds $\cdot$ Circulation patterns $\cdot$ Self-organizing maps

\section{Introduction}

During austral winter, the atmospheric circulation in South America is characterized by the retreat of the South America Monsoon System and by the weakening of deep convection in the southern and central Amazon regions (Vera et al. 2006; Garreaud et al. 2009; Marengo et al. 2010). The anticyclones intensification over southern oceans and the displacement of the South Atlantic anticyclone towards the continent further favour the strengthening of the southeasterly trade winds (Fig. 1a).

At subseasonal timescales, tropical and subtropical South America also experiences large dynamical and thermodynamical variations during this season (Satyamurty et al. 1998). Southern winds incursions from high latitudes, also called cold surges, are known to modulate the day-today atmospheric variability and to penetrate into subtropical and tropical South America, inducing severe temperature drops (e.g. Marengo et al. 1997; Garreaud and Wallace 1998; Pezza and Ambrizzi 2005). These cold surges episodes have been extensively described for 


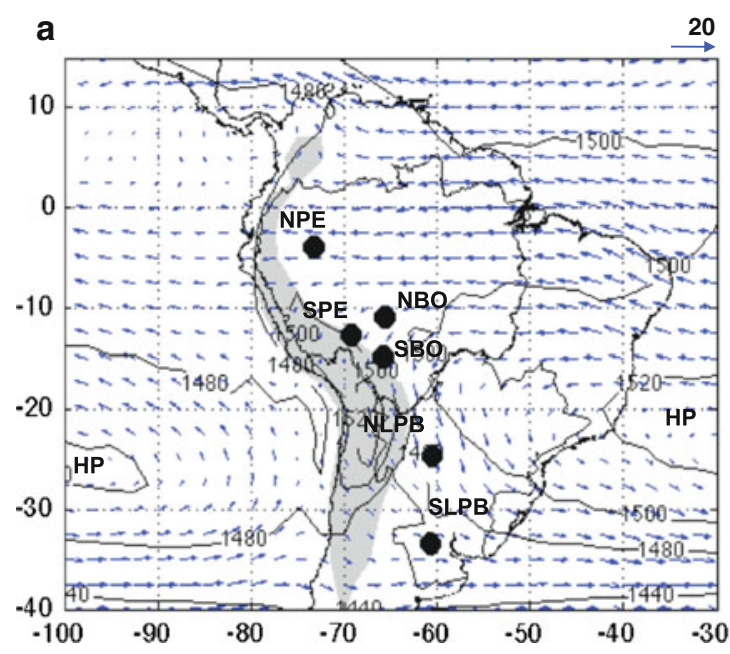

Fig. 1 a 1967-2002 mean geopotential height and total wind at $850 \mathrm{hPa}$ for June-July-August (JJA) season. Atmospheric data are from ERA-40 reanalysis. b Mean temperature at $2 \mathrm{~m}$ for JJA season.

Argentina (e.g. Rusticucci and Vargas 1995; Vera and Vigliarolo 2000; Müller et al. 2000; Penalba et al. 2007; Bettolli et al. 2010) and in southern Brazil where "friagens", their name in Portuguese, repeatedly produced frost and severely impacted coffee plantations during the last century (Hamilton and Tarifa 1978; Fortune and Kousky 1983; Marengo et al. 1997). These dramatic impacts explain the considerable attention devoted to these events in the subtropics of South America and foster research on the identification of precursors (e.g. Fortune and Kousky 1983; Krishnamurti et al. 1999; Vera and Vigliarolo 2000; Müller and Ambrizzi 2007; among others).

Cold surges occur mainly during austral winter and follow three main south-north trajectories, one along the Atlantic coast, the second along the Parana River axis and the third one between the Brazilian Shield and the Andes (Lupo et al. 2001). According to previous analysis of intense cold surges case studies (e.g. Myers 1964; Parmenter 1976; Hamilton and Tarifa 1978; Fortune and Kousky 1983; Marengo et al. 1997, Garreaud and Wallace 1998; Li and Treut 1999; Garreaud 1999, 2000; Lupo et al. 2001), they originate from transient cold core high-pressure centres that move eastward onto the southern tip of South America from the Pacific Ocean, and further intensify while crossing continental Argentina a couple of days later. These high-pressure displacements have been usually related to eastward moving mid-latitude Rossby wave trains originating from the westerly storm track in the South Pacific (Kiladis and Weickmann 1992; Ambrizzi and Hoskins 1997; Müller and Ambrizzi 2007). They are preceded by cold fronts that tend to be channelled to the north immediately to the east of the Andes fostering the advance of cold air toward north (Seluchi and Marengo 2000; Vera and Vigliarolo 2000; Seluchi et al. 2006).

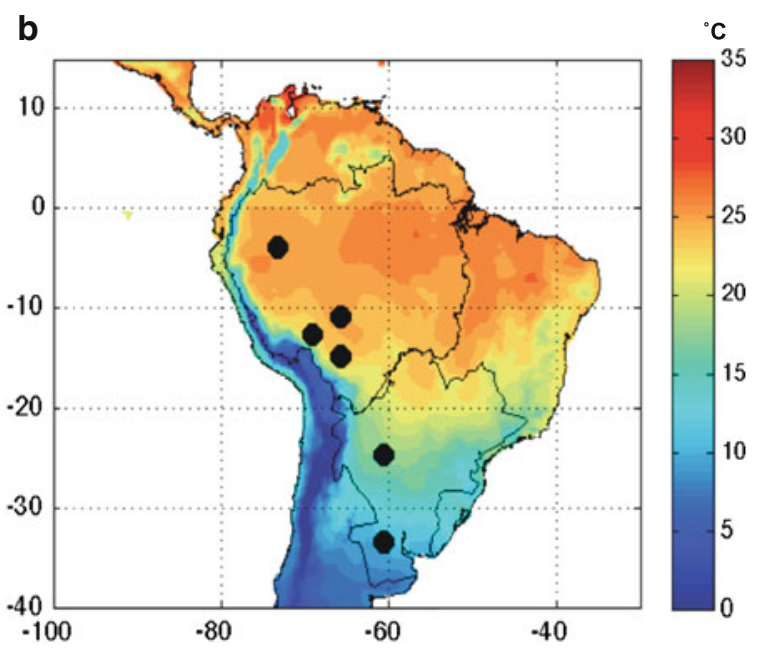

JJA mean temperature fields are computed using the CRU dataset (Mitchell and Jones 2005) for the 1967-2000 period. The situations of virtual stations defined in Sect. 2.1 are shown in the maps

Compagnucci and Salles (1997) showed that the atmospheric pattern associated to the passage of anticyclones and cyclones and their associated frontal systems is the second more recurrent synoptic pattern in Argentina and Chile. More recently, the partition of daily atmospheric situations into broad categories of recurrent spatial largescale atmospheric circulation patterns (CPs) or weather regimes have allowed to relate the typical circulation features in southern South America to the local meteorological variations (e.g. Solman and Menéndez 2003; Bischoff and Vargas 2003; Müller et al. 2003; Bettolli et al. 2010). Solman and Menéndez (2003) for instance demonstrated that a specific transition of weather regimes, with an eastward progression of a low geopotential height near the surface over the South Atlantic Ocean, followed by an intense cold anticyclone over the south of the continent, are responsible for sustained cold conditions over Patagonia and northern Argentina. In agreement with Müller et al. (2003), the above-mentioned atmospheric conditions result in southern winds originating from the pole responsible for advective and/or radiative frost in the Pampa Húmeda region.

Cold surge do not only affect the South American subtropics and have also been reported to propagate towards the equatorial region, reaching Colombia and Venezuela on the western trajectory (Parmenter 1976; Poveda et al. 2006; Myers 1964) and northeast Brazil on the eastern one (Kousky 1979). In the western Amazon region, cold surges are sufficiently remarkable to be identified as "Friajes" or "Surazos" in Spanish speaking countries. They are characterized by sudden and severe drops in temperature, as much as $10{ }^{\circ} \mathrm{C}$ from 1 day to another, and may hence temporarily affect people and crops not used to these very low values. They can also affect the population health in 
Peruvian and Bolivian Amazon, in particular children that may contact respiratory diseases (e.g. Epidemiological Bulletin No 30 of Health Regional Bureau of Loreto-Peru, July 2011. http://www.diresaloreto.gob.pe/portal/).

However, in low latitude regions and particularly in the western Amazon region, cold surges are less documented than in the subtropics and, with the exception of some "grey literature" (Marengo 1983, 1984; Ronchail 1989a, b; Oliveira and Nobre 1986; Flores 2001; Montes de Oca 1995; Quispe 2005, 2010), studies are limited to extreme case studies (e.g. Marengo et al. 1997) and generally do not use ground in situ data (e.g. Garreaud and Wallace 1998; Garreaud 2000; Lupo et al. 2001). While the above mentioned works have related the atmospheric circulation to cold surges in the southern tip of South America, the progression of the cold surges into the deep tropics and their associated typical circulation patterns have not been yet systematically described. The connection between subtropical and tropical weather systems has however recently been discussed by Espinoza et al. (2012). They evidenced the well-organized temporal evolution of the atmospheric circulation in the Amazon basin into a cycle of 7 phases or circulation patterns (CPs) and attributed this temporal organisation to eastward moving extra tropical Rossby waves and their incursion towards low latitude. They also demonstrated that the northward propagation of rainfall from the La Plata basin to Northwest Amazon is related to alternating negative and positive geopotential anomalies on the Southern Pacific and Atlantic oceans and over the South American continent, which drive a northward progression of southern winds anomalies. A thorough description of the relationship between CPs and temperature along the eastern flank of the Cordillera is however still lacking.

The first goal of the present study is hence to provide a detailed description of the propagating features of cold surges and of their incursion into the Amazon region during wintertime, using in situ temperature values collected all along the eastern flank of the Andes, from the extratropics to the equatorial regions of South America over the 1975-2001 period. We also aim relating these cold episodes to the large-scale atmospheric circulation patterns described in Espinoza et al. (2012), in order to determine whether some CPs are associated with and/or are precursors of extreme cold events, with a special attention devoted to near equatorial regions less documented than subtropical regions. In particular, we aim at identifying the atmospheric conditions that favour the propagation of cold surges from southern South America to equatorial regions. Finally, two cases of severe cold intrusions into the tropical and equatorial regions on the eastern flank of the Andes are detailed.

The paper is organized as follows. A description of the observed and reanalysed atmospheric data used in this study is first provided in Sect. 2. Section 3 then describes the temporal characteristics of cold surges. The large scale dynamics related to cold surges is analyzed using circulation patterns (CPs) near the ground in Sect. 4 and compositing atmospheric variables near the ground and at $200 \mathrm{hPa}$ during the days surrounding the cold surge occurrence, in Sect. 5. The specificity of the atmospheric dynamics of cold surges propagating towards the equator are analysed in Sect. 6. In Sect. 7, two cases of intense cold surges in Bolivian and Peruvian Amazon are commented. Finally, concluding remarks are given in Sect. 8.

\section{Data description and extreme events definition}

\subsection{Observed in-situ temperature dataset}

Extreme cold events are identified in this study using in situ daily minimal temperature $\left(\mathrm{T}_{\min }\right)$ for June-July-August (JJA) season. $\mathrm{T}_{\min }$ observations have been collected along the eastern side of the Andes in the extra-tropical (Argentina), tropical (Bolivia and South of Peru) and equatorial regions (North of Peru) of South America, during the 1975-2001 period (Table 1; Fig. 1). Temperature data are provided by the Argentinean National Meteorological Service (SMN), the Bolivian National Service of the Meteorology and Hydrology (SENAMHI-Bolivia), the Peruvian National Service of Meteorology and Hydrology (SENAMHI-Peru) and the Peruvian Corporation for Airports and Commercial Aviation (CORPAC). These institutes have performed stringent quality control procedures to ensure high accuracy standards. The selected stations present less than $10 \%$ of missing values in their JJA time series. Outliers, defined as the temperature exceeding the third quartile plus three times the interquartile range, are first identified. These outliers are then compared to nearby stations values and are finally discarded if they do not match with neighbouring stations. Using these data, we further create virtual stations for each region of interest by averaging daily data from the two closest stations. This procedure allows preserving the continuity of time series as well as smoothing part of the small-scale variability hence providing a temperature more representative of the synoptic scale. Associated stations are: Pergamino and Rosario in Southern La Plata basin (SLPB), Las Lomitas and Presidencia Saenz Peña in Northern La Plata basin (NLPB), Trinidad and San Borja in central Bolivia (SBO), Guayaramerín and Riberalta in Northern Bolivia (NBO), Puerto Maldonado in Southern Peruvian Amazon (SPE) and Tamshiyacu and Iquitos in Northern Peruvian Amazon (NPE). The geographical locations of the virtual stations are shown in Fig. 1 and Table $1 . \mathrm{T}_{\min }$ in pairs of neighbouring stations are highly correlated during the austral 
winter. The strongest relationships are found in the subtropical South America, with correlations exceeding 0.9, while these relationships weaken in the tropical regions (Table 1). These regional differences can be explained as follows. Temperature changes in the southern part of the domain are largely controlled by the advection of air masses from the ocean, resulting in synoptic atmospheric events which impact large regions, which could explain the high correlation between the temperatures of nearby stations in the southern regions. In contrast, tropical regions are strongly affected by small-scale cloudiness related to convective processes, which could result in weaker correlation coefficients between temperatures of neighbouring stations.

\subsection{Reanalysis ERA-40}

The description of the atmospheric circulation is based on daily values of the 40-year European Centre for MediumRange Weather Forecast (ECMWF) Re-Analysis (ERA40, Uppala et al. 2005). ERA-40 data are available on a $2.5^{\circ} \times 2.5^{\circ}$ grid resolution (http://data-portal.ecmwf.int/ data/d/era40_daily). ERA-40 $850 \mathrm{hPa}$ zonal and meridional winds at each grid point in the region between $10^{\circ} \mathrm{N}$ and $30^{\circ} \mathrm{S}$ and $50^{\circ} \mathrm{W}$ and $80^{\circ} \mathrm{W}$ are used to define CPs. Moreover, the structure of the atmosphere during cold spells are described using ERA-40 minimum temperature at $2 \mathrm{~m}$ as well as temperature, specific humidity, horizontal and vertical winds speed at 1,000, 925, 850, 700, 600, 500, 300 and $200 \mathrm{hPa}$. ERA-40 minimum temperature at $2 \mathrm{~m}$ during JJA compares well with observed $T_{\min }$ in each of the selected station (not shown), with correlation values reaching 0.94 over the north and south La Plata basin, 0.80 in Bolivian Amazon and SPE, and 0.55 in NPE.

\subsection{The NOAA outgoing longwave radiation data}

The daily interpolated Outgoing Longwave Radiation (OLR) data from NCAR/NOAA (Liebmann and Smith 1996) are used over the period of study as a proxy for deep convection (e.g. Lau and Chan 1986; Liebmann et al. 1999; Jones et al. 2004). This dataset allows describing the convective activity related to the circulations patterns and cold fronts.

\subsection{Definition of extremes cold events}

Along the eastern side of the Andes, austral winter (JuneJuly-August, JJA) climatological temperature increases northward, from $5{ }^{\circ} \mathrm{C}$ in the southern La Plata basin to $20{ }^{\circ} \mathrm{C}$ in the equatorial Amazon (Fig. 1b; Table 1). Averaged daily minimal temperature $\left(\mathrm{T}_{\min }\right)$ during JJA is $5.4{ }^{\circ} \mathrm{C}$ in SLPB (Table 1). In this region, the westerly subtropical low-level flow prevails (Fig. 1a). Heading North, austral winter $\mathrm{T}_{\min }$ reaches $11.2^{\circ} \mathrm{C}$ in $\mathrm{NLPB}, 16.9^{\circ} \mathrm{C}$ in $\mathrm{SBO}$, and $18.0^{\circ} \mathrm{C}$ in NBO and in SPE. There, northerly winds originating from the South Atlantic Anticyclone dominate. In northern Peruvian Amazon, easterly trade winds prevail and $\mathrm{T}_{\text {min }}$ is high, reaching $20.6{ }^{\circ} \mathrm{C}$ (Fig. 1a), thanks to the strong insolation all year round. Figure 2 further illustrates the specific distribution of $\mathrm{T}_{\text {min }}$ data in austral winter depending on the station considered. The amplitude of variability is far larger in the South, where $T_{\min }$ values range from -4 to $20^{\circ} \mathrm{C}$ in SLPB. In the Northern part of La Plata basin, around $25^{\circ} \mathrm{S}$, frost as well as temperature greater than $25{ }^{\circ} \mathrm{C}$ can be observed. Consistently, the standard deviation of winter temperature is large in both southern stations $\left(4.9\right.$ and $5.9{ }^{\circ} \mathrm{C}$ respectively in SLPB and $\mathrm{NLPB}$ ), as well as the differences between mean $\mathrm{T}_{\min }$ and

Table 1 Geographical situation of ground stations and related virtual stations

\begin{tabular}{|c|c|c|c|c|c|c|c|c|c|}
\hline Station & Lat. & Lon. & $\begin{array}{l}\text { Virtual } \\
\text { station }\end{array}$ & Corr. (r) & $\begin{array}{l}\text { Mean } \\
\mathrm{T}_{\min }\left({ }^{\circ} \mathrm{C}\right)\end{array}$ & $\begin{array}{l}\text { 10th } \\
\text { Ptile. }\left({ }^{\circ} \mathrm{C}\right)\end{array}$ & STD $\left({ }^{\circ} \mathrm{C}\right)$ & $\begin{array}{l}\text { CSd } \\
\text { (days) }\end{array}$ & $\begin{array}{l}\text { CS by } \\
\text { year }\end{array}$ \\
\hline Pergamino & -33.56 & -60.55 & \multirow[t]{2}{*}{ SLPB } & \multirow[t]{2}{*}{0.93} & \multirow[t]{2}{*}{5.4} & \multirow[t]{2}{*}{-0.8} & \multirow[t]{2}{*}{4.9} & \multirow[t]{2}{*}{2.8} & \multirow[t]{2}{*}{3.2} \\
\hline Rosario & -32.92 & -60.78 & & & & & & & \\
\hline Presidencia Sanez Peria & -26.82 & -60.45 & \multirow{2}{*}{ NLPB } & \multirow{2}{*}{0.91} & \multirow{2}{*}{11.2} & \multirow[t]{2}{*}{2.7} & \multirow[t]{2}{*}{5.9} & \multirow[t]{2}{*}{2.5} & \multirow[t]{2}{*}{3.6} \\
\hline Las Lomitas & -24.70 & -60.58 & & & & & & & \\
\hline San Borja & -14.85 & -66.73 & \multirow[t]{2}{*}{ SBO } & \multirow[t]{2}{*}{0.79} & \multirow[t]{2}{*}{16.9} & \multirow[t]{2}{*}{12.2} & \multirow[t]{2}{*}{3.3} & \multirow[t]{2}{*}{2.7} & \multirow[t]{2}{*}{3.4} \\
\hline Trinidad & -14.82 & -64.90 & & & & & & & \\
\hline Riberalta & -11.00 & -66.10 & \multirow{2}{*}{$\mathrm{NBO}$} & \multirow{2}{*}{0.62} & \multirow[t]{2}{*}{18.0} & \multirow[t]{2}{*}{13.8} & \multirow[t]{2}{*}{3.0} & \multirow[t]{2}{*}{2.7} & \multirow{2}{*}{3.3} \\
\hline Guayaramerin & -10.82 & -65.34 & & & & & & & \\
\hline Puerto Maldonado & -12.40 & -69.10 & SPE & - & 18.0 & 13.5 & 3.3 & 2.6 & 3.4 \\
\hline Tamshiyacu & -4.00 & -73.16 & \multirow[t]{2}{*}{ NPE } & \multirow[t]{2}{*}{0.72} & \multirow[t]{2}{*}{20.6} & \multirow[t]{2}{*}{18.9} & \multirow[t]{2}{*}{1.4} & \multirow[t]{2}{*}{3.0} & \multirow[t]{2}{*}{3.0} \\
\hline Iquitos & -3.75 & -73.25 & & & & & & & \\
\hline
\end{tabular}

Coefficients of correlation between $\mathrm{T}_{\text {min }}$ of pairs of stations ( $\mathrm{r}$ ), mean $\mathrm{T}_{\min }$, 10th percentiles of $\mathrm{T}_{\min }$, standard deviation (STD), mean duration of cold surges (CSd) and annual number of cold surges (CS) during the June-July-August (JJA) season are indicated 
$\mathrm{T}_{\text {min }}$ 10th percentile (Table 1 ). In contrast, $\mathrm{T}_{\min }$ range is weaker in Bolivia and northern Peru, especially in NPE where the standard deviation $\left(1.3{ }^{\circ} \mathrm{C}\right)$ and the differences between mean $\mathrm{T}_{\text {min }}$ and $\mathrm{T}_{\text {min }}$ 10th percentile are far smaller. Figure 2 also reveals that highest temperatures are relatively similar for all stations while lowest temperatures strongly differ, depending on the latitude. It is hence not possible to define cold days for all stations based on a common threshold. Extreme cold days in each virtual station are therefore defined as days when $\mathrm{T}_{\text {min }}$ drops below the tenth percentile of $\mathrm{T}_{\text {min }}$ distribution (black dotted line in Fig. 2). The beginning of an extreme cold event in SLPB is then defined as the first day when $\mathrm{T}_{\text {min }}$ drops below the 10th percentile corresponding to a $-0.8{ }^{\circ} \mathrm{C}$ threshold, similar to the one used by Müller et al. (2000) to define cold days over the Pampa Húmeda region in Argentina $\left(0{ }^{\circ} \mathrm{C}\right)$. The end of the cold event is then identified as the first day when $T_{\min }$ exceeds the 10th percentile for four consecutive days. Using this definition, the number of cold surges is about 3-3.6 each winter. They last from 2.5 to 3 days depending on the station (Table 1). Moreover, cold surges are more frequent in July (50\% of cases) while $25 \%$ of the cases are observed in June and August. Using the 5th percentile as threshold for defining the extreme events results in a smaller number of events identified but in similar relationship between minimum temperature values and atmospheric circulation characteristics.

\section{Temporal characteristics of cold surges on the eastern flank of the Andes}

The temporal characteristics of cold surges identified in the virtual stations described above are further explored in this section. First, a composite analysis of $\mathrm{T}_{\min }$ in each station is built for all cold days occurring over the 1975-2001 period (around 250 cases). After an abrupt $\mathrm{T}_{\text {min }}$ decrease between day $\mathrm{D}-2$ and day $\mathrm{D}+0$ in $\operatorname{SLPB}\left(\sim 5^{\circ} \mathrm{C}\right)$, a cold event starts in

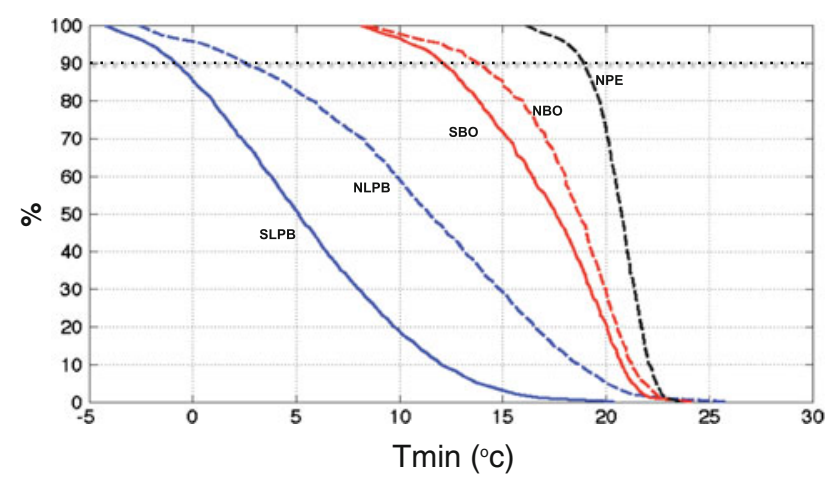

Fig. 2 Accumulated Probability Density Function for JJA $\mathrm{T}_{\text {min }}$ (1975-2002 period). Blue, blue dashed, red, red dashed and black dashed lines are for SLPB, NLPB, NBO and NPE, respectively
SLPB at day $\mathrm{D}+0$, the first day when $\mathrm{T}_{\text {min }}$ drops below the 10th percentile (Fig. 3a). Very cold temperatures are then generally monitored at day $\mathrm{D}+1$ in NLPB and at day $\mathrm{D}+2$ in the tropical stations (SBO, NBO and SPE). It takes two to three days for a cold surge to reach the equatorial region in NPE. $\mathrm{T}_{\text {min }}$ drop is smaller in tropical $\left(\sim 2{ }^{\circ} \mathrm{C}\right)$ and equatorial $\left(0.8^{\circ} \mathrm{C}\right)$ stations than in subtropical regions (Fig. 3a). Cold anomalies however last about 2 days in northernmost stations, while a rapid $\mathrm{T}_{\min }$ increase is observed in SLPB and NLPB during the 2-days following the coldest $\mathrm{T}_{\min }$.

Figure $3 \mathrm{~b}$ displays the percentage of cold days in all virtual stations observed within 5 days following the cold surge appearance in SLPB. Extreme cold events in NLPB are usually initiated the same day (25\% of the cases) or 1 day later (30\% of the cases) than in SLPB. Their frequency then rapidly decreases to nearly vanish after 3 days. Further north, cold surges in SBO, NBO, and SPE are usually observed within 2 days $(>55 \%)$ after detecting a cold event in SLPB, with a maximum probability after 1 day $(>20 \%)$. This probability drops to $10 \% 3$ days later to become rare after 4 and 5 days $(\sim 5 \%)$. In NPE, this probability is relatively similar within the first 3 days (from $\mathrm{D}+0$ to $\mathrm{D}+2(\sim 15 \%))$. A significant percentage of cold events $(13 \%)$ develop in NPE 3 days after the beginning of a cold surge in SLPB. This probability then slowly decreases for longer lags (Fig. 3b).

Computing the total percentage of extreme cold surges in each virtual station (Fig. 3c) reveals that $68 \%$ of the cold surges reported in NPE have also been reported in SLPB during the 5 preceding days. This percentage is higher for other stations, ranging from $\sim 75 \%$ in SPE, NBO and SBO to $81 \%$ in NLPB. The lower percentage in NPE could be related to the higher probability for the cold surge to dissipate in NPE due to its distance from SLPB.

Our dataset also allows diagnosing the persistence of these cold episodes in each of the selected virtual stations. Figure $3 \mathrm{c}$ displays the percentage of cold episodes that last from 1 to 7 days. $\sim 60 \%$ of the cold surges in SLPB lasts for 1-day while $\sim 25$ and $\sim 8 \%$ respectively persist during 2 and 3 days. Cold surges duration is slightly larger in the northern stations: cold surges lasting a single day represent $45-50 \%$ of the cases while cold surges lasting 3 and 4 days represent respectively 15 and $10 \%$ of the cases (Fig. 3c). Persistence of more than 5 days is very rare for all stations (less than $5 \%$ of the cases), representing $0.5 \%$ of the cases in NLPB and about $5 \%$ in NPE.

\section{Large-scale circulation patterns and related cold surges}

This section describes the methodology used to classify the daily meteorological situations of all the winter days over 

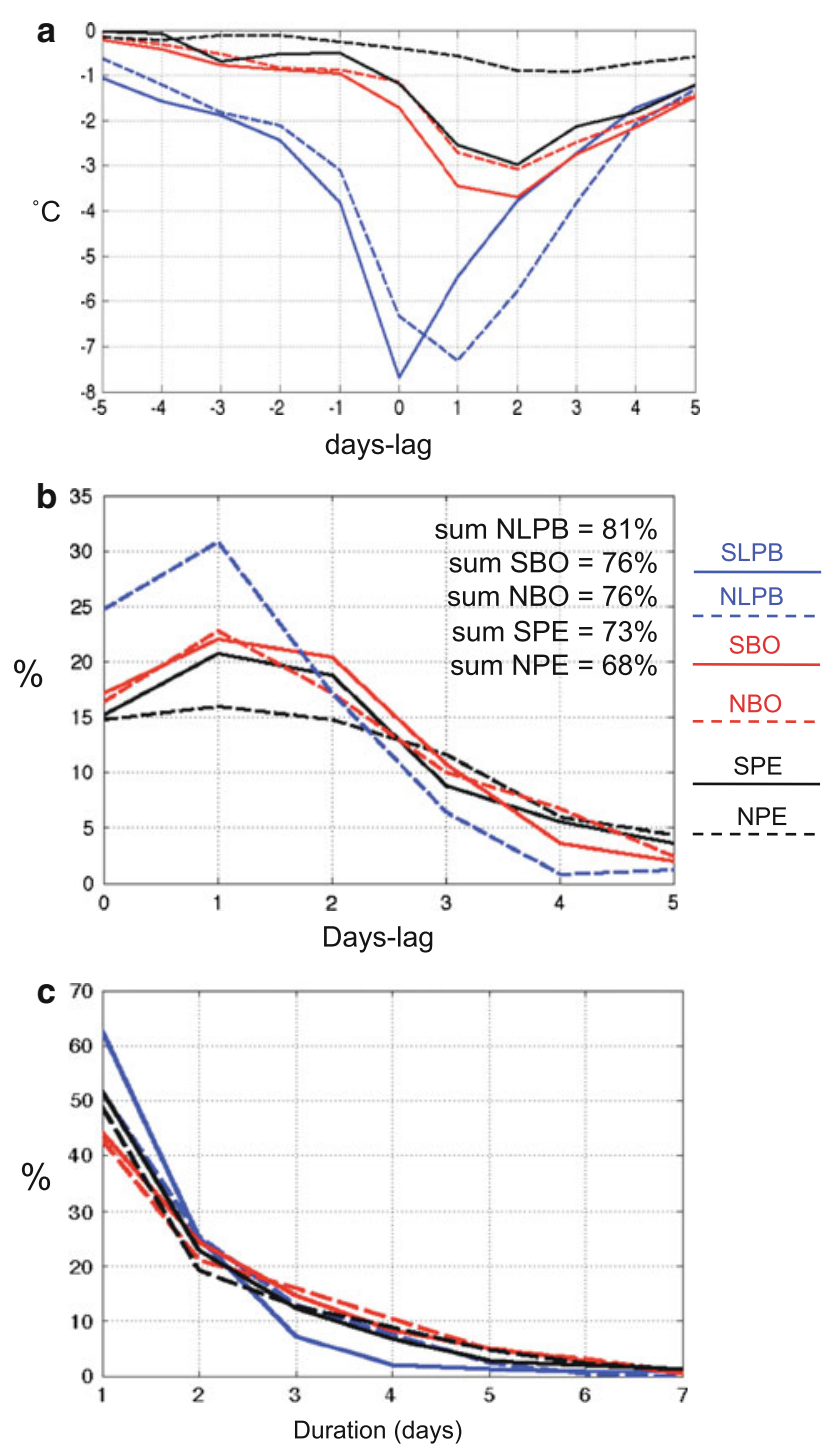

Fig. 3 a Composites of winter $T_{\min }$ anomalies (1975-2002) for each station during the 10 days period surrounding $\mathrm{D}+0$. $\mathrm{D}+0$ is defined as the first day when $T_{\text {min }}$ is below the 10th percentile in SLPB. b Percentage of cold surge observed in each virtual station after the beginning of a cold surge in SLPB. A time-lag from 0 to 5 -days is considered. The sums of the percentages of cases of cold surges in each station are indicated. c Percentage of extreme $\mathrm{T}_{\text {min }}$ events with a duration of one to 7-days. Extreme $\mathrm{T}_{\min }$ event is defined considering days with temperatures below the 10th percentile of $T_{\text {min }}$

the 1975-2001 period into circulation patterns (CPs) and to relate the occurrence of cold surges to these CPs. While most previous studies describing the atmospheric circulation related to cold events used composite techniques of the atmospheric conditions before, during and after the cold event, the proposed methodology differs substantially because CPs and cold events are first independently identified. Their relationships are then analysed a posteriori, investigating whether or not cold surges occur during specific CPs.

\subsection{Clustering daily atmospheric conditions}

Large-scale circulation patterns (CPs) or weather regimes are defined in tropical South America around the Amazon basin. In this study as in Espinoza et al. (2012), daily meteorological situations are characterized by 60-days high-pass filtered zonal and meridional components of the $850 \mathrm{hPa}$ wind defined onto a $17 \times 13$ grid points of a geographical map $\left(10^{\circ} \mathrm{N}-30^{\circ} \mathrm{S}\right.$ and $\left.50^{\circ} \mathrm{W}-30^{\circ} \mathrm{W}\right)$. Our clustering approach combines a non-linear Self-organizing maps method (SOM; Kohonen 1984, 2001) followed by a hierarchical agglomerative clustering method (HAC, Jain and Dubes 1988). This hybrid approach has already been successfully implemented to define circulation patterns over West Africa (Gueye et al. 2010) and over the Amazon basin (Espinoza et al. 2012).

Self-organizing maps is a non-linear and unsupervised clustering algorithm that allows analysing high dimensional data sets by creating a spatially organized set of general variability patterns from the data. For technical aspects of the algorithm, one can refer to Kohonen (2001) for the general and theoretical formulation and to Richardson et al. (2003) for information on how to apply it in climate sciences (in particular, their Fig. 2 which summarizes well the implementation of the SOM). In our study, the learning dataset gathers 2,484 daily meteorological situations over the 27 JJA seasons (1975-2001). Basically, the SOM algorithm makes a nonlinear projection of the learning data set onto a two-dimensional array of neurons usually called Kohonen map (here, a $7 \times 7$ map). Once the SOM is trained, each input data (i.e. each daily atmospheric situations) is connected to a neuron and a group of input data projected onto a same neuron forms a cluster. Each neuron of the Kohonen map is defined by a reference vector, summarizing the meteorological situations contained in a subset of the learning set sharing common statistical properties, and its position on the Kohonen map. On the map, nearby neurons correspond to similar patterns. More information about this method is provided in Leloup et al. $(2007,2008)$ and Hewitson and Crane (2002).

Details about the SOM and its advantages with regards to other classification methods such as the k-means can be found in Badran et al. (2004). Shortly, the SOM algorithm is a generalization of k-means, allowing a more refined clustering especially when the data set may be partitioned in form of an erratic cluster set. This is due to the fact that the SOM algorithm uses in the cluster determination specific terms that take into account the topology of the cluster map, through some distance between the associated cluster neighbourhoods. Then SOM allows preserving topological relations, i.e. patterns that are close in the input space will be mapped onto neurons that are close on the Kohonen 
map, and vice versa, then enabling easy visualization. Moreover, SOM is less sensitive to the initialization choices and is less prone to local optima than k-means.

Figure 4 illustrates the characteristics of the Kohonen map after applying the SOM algorithm to the 2,484 daily $850 \mathrm{hPa}$ zonal and meridional winds for the JJA season. Figure $4 \mathrm{a}$ displays the number of daily meteorological situations projected on each neuron of the map. The daily atmospheric conditions associated with cold events for each virtual station (defined in Sect. 2.4) can then be identified on the Kohonen map (Fig. 4c). Daily meteorological situations described by the reference vectors corresponding to nine selected neurons (located on the edges of the Kohonen map, indicated in Fig. 4a) are also displayed in Fig. 4b. This methodology allows identifying the large-scale meteorological situations associated with extreme cold events. As shown on Fig. 4c, cold surges mainly project onto the lower part of the map and are hence associated to specific atmospheric conditions where southern winds prevail (Fig. 4b). Differences in the projections on the map are also observed depending on the virtual station considered: cold days in SLPB largely project onto the right hand side of the map, characterized by south-eastern winds over the whole domain while cold episodes in NPE mainly project onto the left hand side of the Kohonen map, where southern winds anomalies prevail in the Amazon region in association with an anticyclonic circulation over La Plata basin. The discrimination of extreme cold days on the Kohonen map also appear to be clearer in the Argentinean stations when compared to the Bolivian and Peruvian ones. In SLPB and NLPB extreme cold events are largely gathered in the lower right corner of the Kohonen map while in the Peruvian and Bolivian stations cold events display a larger spread on the map (Fig. 4c). This result suggests that cold days in La Plata basin are tightly related to specific atmospheric conditions, while cold episodes in the Amazon region may arise from small-scale cloudiness anomalies, not related to large-scale atmospheric disturbances. This will be further discussed in Sect. 6.

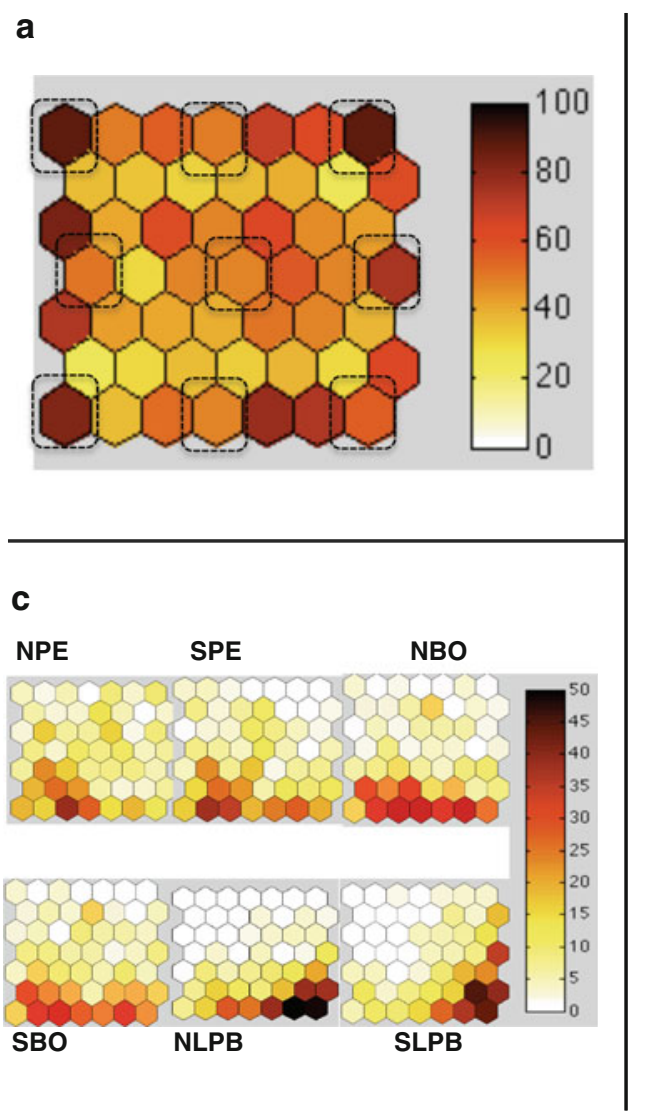

Fig. 4 a Kohonen map computed with daily zonal and meridional winds at $850 \mathrm{hPa}$ for JJA season over the 1975-2002 period in the region $10^{\circ} \mathrm{N}-30^{\circ} \mathrm{S} ; 50^{\circ} \mathrm{W}-80^{\circ} \mathrm{W}$. The total number of days projected on the Kohonen map is indicated in the vertical scale. b Subseasonal wind (arrows) anomalies at $850 \mathrm{hPa}$ representative of nine extreme
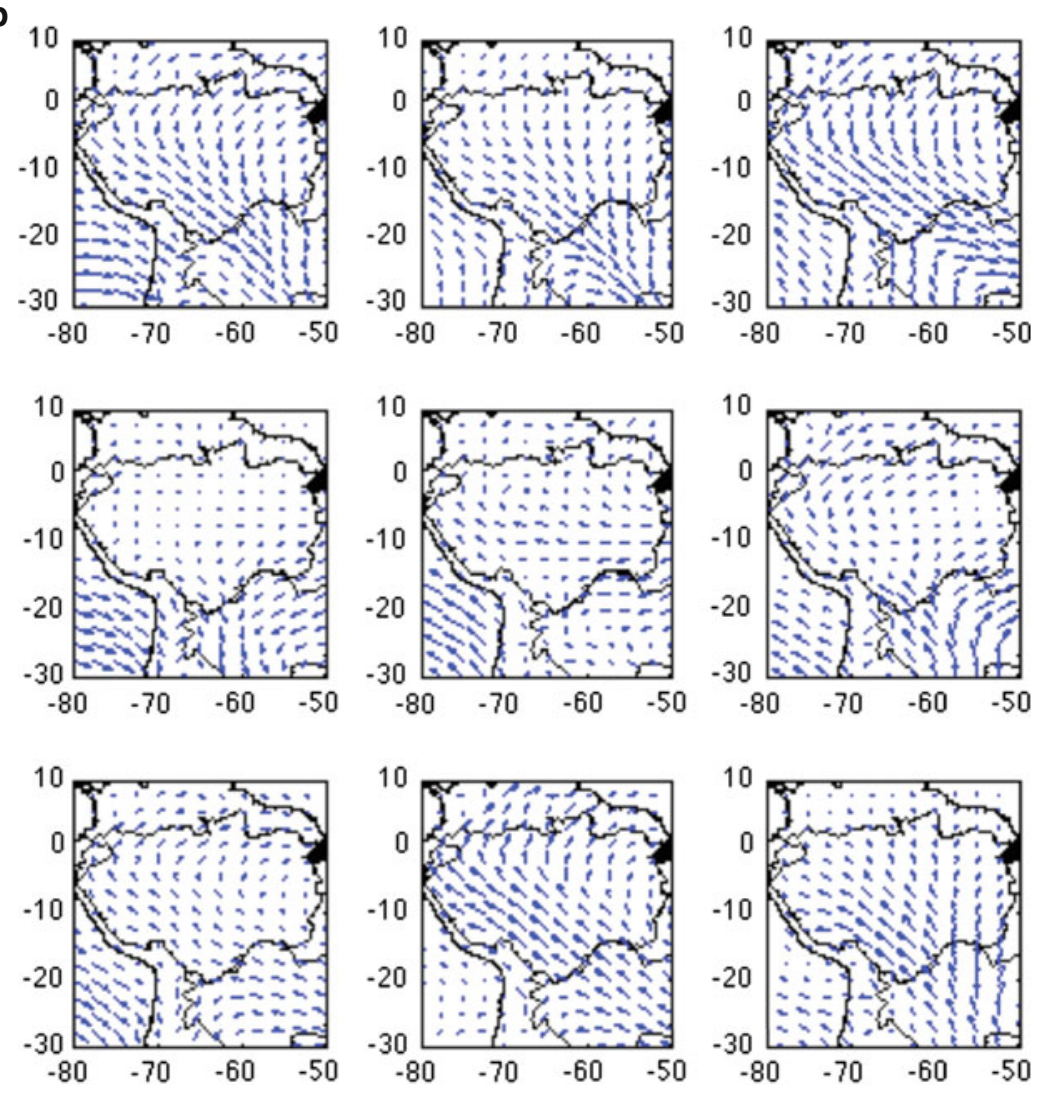

neurons highlighted in panel a (the values are normalized at each gridpoint by their standard deviation). Limits of the Amazon, La Plata basin and South America are indicated. $\mathbf{c}$ Percentage of extreme $\mathrm{T}_{\min }$ days projected onto each neuron of the Kohonen map for each virtual station at the east of the Andes 
4.2 Circulation Patterns (CP) definition and characterization

Following the methodology from Espinoza et al. (2012), the 49 reference vectors of the Kohonen map can be aggregated into a smaller number of clusters based on the similarities of the reference vectors using a Hierarchical Agglomerative Clustering (HAC, Jain and Dubes 1988) algorithm, that aggregate reference vectors displaying similar large-scale low level circulation. The seven classes resulting from applying $\mathrm{SOM}$ and $\mathrm{HAC}$ algorithms are defined as the seven circulation patterns (CPs) for JJA season (Fig. 5). Surface temperature anomalies from ERA40 and observed Outgoing Longwave Radiation (OLR) anomalies from NOAA dataset corresponding to each CP are also superimposed on each CP map (Fig. 5b). Finally, transition probabilities between CPs and the persistence of each $\mathrm{CP}$ are computed to capture the CPs temporal evolution (Fig. 5a). The transition measures the probability for a CP to be followed by another CP (arrows in Fig. 5a). Persistence measures the probability for a $\mathrm{CP}$ to persist from 1 day to another (circles in Fig. 5a). As noticed by Espinoza et al. (2012), the evolution between the different CPs is organized into a cycle, each CP featuring a stage of the northward progression of southern wind anomalies and of their convergence with the trade winds from the La Plata basin to the Amazon basin, (Figs. 5b-2, b-6), followed by the recovery of a northwestern circulation (Fig. 5b-7, b-2).

A quantitative measure relating extreme cold events with CPs can be obtained by using the $\mathrm{I}_{\mathrm{k}}$ index introduced by Espinoza et al. (2012) and defined in Eq. 1:

$I_{K}=\left(\frac{P_{J K} / J_{K}}{J_{P T} / J_{T}}-\frac{J_{P T}}{J_{T}}\right) \times 100$

where $\mathrm{P}_{\mathrm{JK}}$ is the number of cold events in the CP K; $\mathrm{J}_{\mathrm{K}}$ is the total number of days projected on the $\mathrm{CP} K$; $\mathrm{J}_{\mathrm{PT}}$ is the total number of cold events in the Kohonen map and $\mathrm{J}_{\mathrm{T}}$ is total number of days on the map (Fig. $4 \mathrm{a}$ ). $\mathrm{I}_{\mathrm{k}}$ indicates the capacity of the CPs to discriminate extreme cold days (strong and positive $\mathrm{I}_{\mathrm{k}}$ ) from the absence of cold days (strong and negative $I_{k}$ ). Zero $I_{k}$ value indicates that the percentage of extreme cold days projected on the $\mathrm{CP}$ considered do not differ from the mean percentage of extreme cold days during JJA season. $\mathrm{I}_{\mathrm{k}}$ values for each virtual station are displayed in Table 2 . This Table a

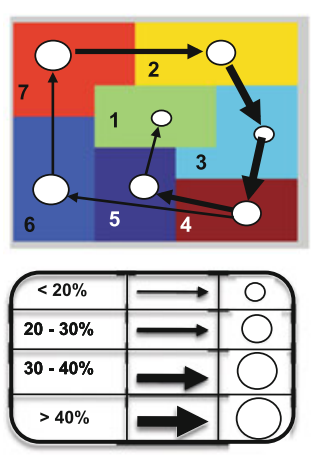

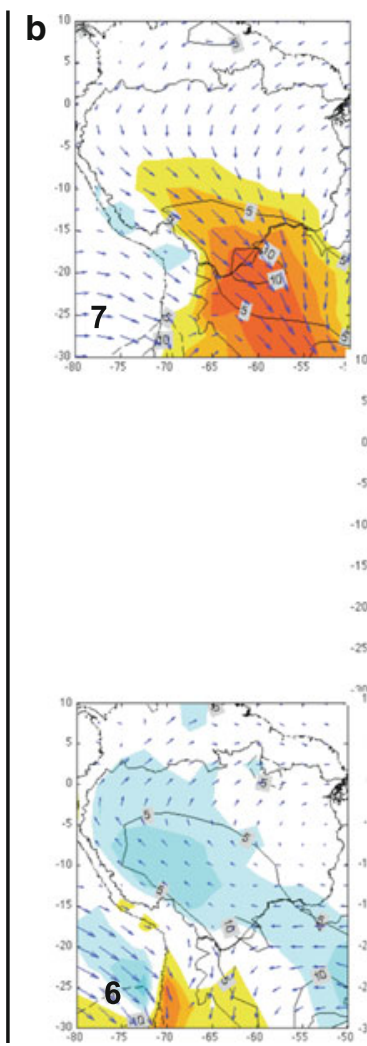

Fig. 5 a Delimitation of the 7 CPs defined on the Kohonen map for JJA (color) and probabilities of persistence (white circles) and transition (black arrows), in percentage. b Subseasonal winds at $850 \mathrm{hPa}$ (vector), minimal temperature at $2 \mathrm{~m}$ of surface (color) from

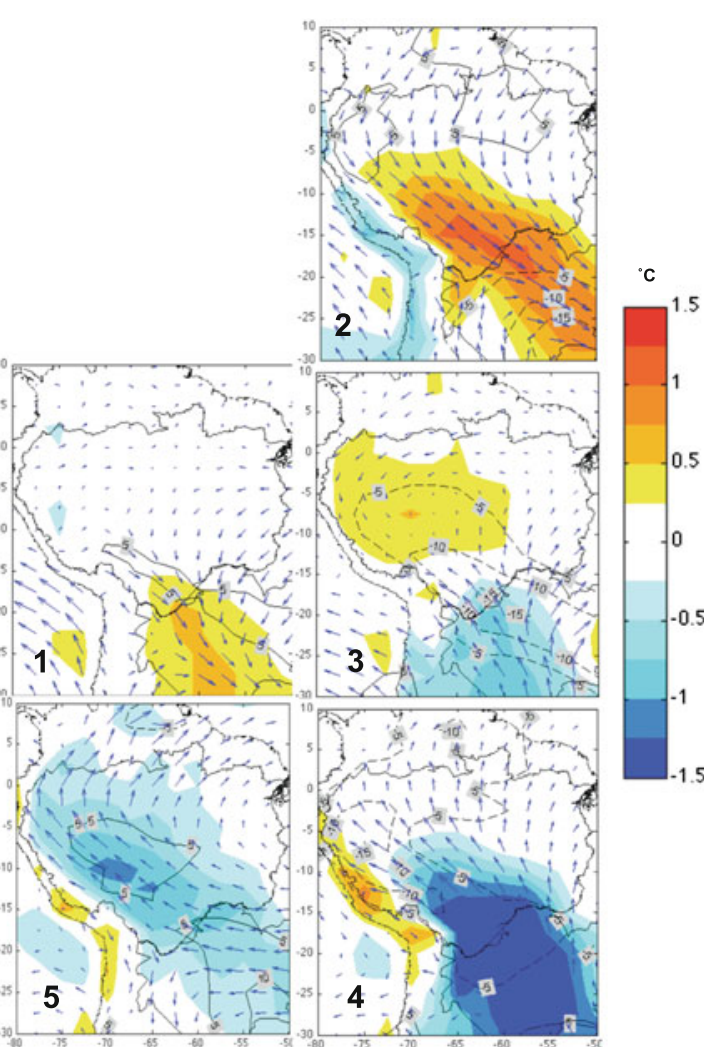

ERA-40 reanalysis, and OLR anomalies (lines) normalized at each grid-point by their standard deviation, associated with each CP. The limit of Amazon, La Plata basins and South America are plotted 
Table $2 \mathrm{I}_{\mathrm{k}}$ values for each virtual station associated to each CP

\begin{tabular}{lrrrrrr}
\hline CP & SLPB & NLPB & SBO & NBO & SPE & NPE \\
\hline 1 & -80 & -87 & -37 & -44 & -21 & -34 \\
2 & -40 & -93 & -83 & -80 & -89 & -44 \\
3 & $\mathbf{1 3 2}$ & 41 & -21 & -49 & -39 & -32 \\
4 & $\mathbf{1 9 0}$ & $\mathbf{2 7 6}$ & $\mathbf{1 2 7}$ & $\mathbf{1 5 8}$ & $\mathbf{1 1 8}$ & 25 \\
5 & -44 & 35 & 92 & $\mathbf{1 2 8}$ & 99 & $\mathbf{1 0 3}$ \\
6 & -59 & -28 & 49 & 33 & 58 & 60 \\
7 & -93 & -93 & -72 & -72 & -64 & -48
\end{tabular}

Values higher than 50 are italics and values higher than 100 are italics and bold italics. $I_{k}$ values are computed using Eq. 1. Positive (negative) $I_{k}$ values indicate an over (under) representation of the occurrence of cold surges during a $\mathrm{CP}$ in a station

indicates that extreme cold events along the eastern side of the Andes mainly occur during CP3 to CP6. Extreme cold events are first noticed in SLPB during CP3 even though cold southern winds appear in Argentina from CP2. During CP4, strongest $I_{k}$ values are observed especially in SLPB and NLPB. During CP4 and CP5, cold events are however observed in nearly all regions east of the Andes. Finally, CP6 is characterized by cold events occurring in NPE, the northernmost region (Table 2; Fig. 5). In addition, cold days in La Plata basin are tightly related to one or two specific CPs (CP3 and CP4), while 3 CPs explain cold conditions in the Amazon region (CP4, CP5, CP6).

\section{Dynamics of the atmosphere during circulation patterns and related cold surges}

A section of daily-standardized anomalies of temperature, horizontal and vertical winds speed and specific humidity east of the Andes (from $73.25^{\circ} \mathrm{W}$ and $3.75^{\circ} \mathrm{S}$ to $52.5^{\circ} \mathrm{W}$ and $35.0^{\circ} \mathrm{S}$; see Fig. 6) allow illustrating the vertical atmospheric structure related to each CP during JJA. This section is oriented along the main axis of the position of the meteorological stations (Fig. 6).

$\mathrm{CP} 3$ is characterized by southern winds anomalies in $\mathrm{La}$ Plata basin. Intense atmospheric convection depicted by large ascending motions in the middle troposphere occurs around $15^{\circ} \mathrm{N}$, consistently with negative OLR anomalies displayed on Fig. 5b-3. Negative temperature and humidity anomalies as well as strong anomalous subsidence are observed over the La Plata basin, south of the convective region (Figs. 5b-3, 6-3) while positive temperature and humidity anomalies appear North of the convective region. During this $\mathrm{CP}$, extreme cold events are hence registered in SLPB (strong positive $I_{k}$ value) and in NLPB (positive $I_{k}$ value), while cold events are not reported further north (Table 2).
During CP4, southern low-level wind anomalies on the eastern flank of the Andes extend northward and further intensify. This results in subsident atmospheric conditions, large negative temperature and specific humidity anomalies in most regions south of $10^{\circ} \mathrm{S}$ (Figs. 5b-4, 6-4). In contrast, weak negative temperature anomalies and large convergence and excess of humidity are observed further north.

During CP5, easterly low-level winds anomalies replaces the southern winds in the Amazon basin in the $15-25^{\circ} \mathrm{S}$ band (Fig. 5b-5). These wind anomalies are deflected northward when approaching the Andes, resulting in southern winds over the Amazon basin north of $15^{\circ} \mathrm{S}$ and subsidence east of the Andes. Cold conditions persist in the Amazon basin in the lower troposphere (under $600 \mathrm{hPa}$ ) combined with a humidity deficit (Fig. 65). $I_{k}$ values from Table 2 further illustrate that cold surges are prominent in the northern part of the domain, from SBO to NPE, regions characterized by low-level southern winds advection, absence of humidity and positive OLR anomalies, while La Plata basin exhibits positive temperature anomalies, in agreement with of northerly low-level winds (Figs. 5b-5, 6-5).

CP6 displays an anticyclonic circulation over La Plata basin, responsible for low level divergence south of the Amazon basin (Fig. 5b-6). Dry and warm conditions combined with anomalous subsidence prevail in the southern Amazon and La Plata basins (Figs. 5b-6, 6-6). The northern part of the Amazon basin is characterized by southern winds anomalies (Fig. 5b-6), combined with cold temperature, dry conditions and subsidence in the middle and low troposphere (Fig. 6-6). These features explain the development of cold events observed in NPE; on the contrary, negatives $\mathrm{I}_{\mathrm{k}}$ values are registered in the La Plata basin (Table 2).

In contrast to $\mathrm{CPs}$ described above, $\mathrm{CP} 1, \mathrm{CP} 7$ and $\mathrm{CP} 2$ are characterized by negative $\mathrm{I}_{\mathrm{k}}$ values all along the eastern flank of the Andes (Table 2). The atmospheric circulation during these CPs is characterized by northern low-level winds and positive anomalies of specific humidity in the low troposphere (Figs. 5b-1, b-2, b-7, 6-1, -2,-7). Positive temperature anomalies also propagate northward from CP5 to $\mathrm{CP} 2$.

To summarize, the above analysis reveals that cold surges propagate northward along the eastern flank of the Andes from CP3 to CP6 driven by the progression of the southern low-level winds toward low latitudes combined with subsidence and dry air in the middle and low troposphere $(1,000-500 \mathrm{hPa})$ that are likely to reinforce cold conditions through a radiative effect, particularly during CP3, CP5 and CP6. Cold surges lag the maximum of convective activity, where cold and dry southern air meets hot and moist northern air, promoting a northward moving cold front (Fig. 5). 

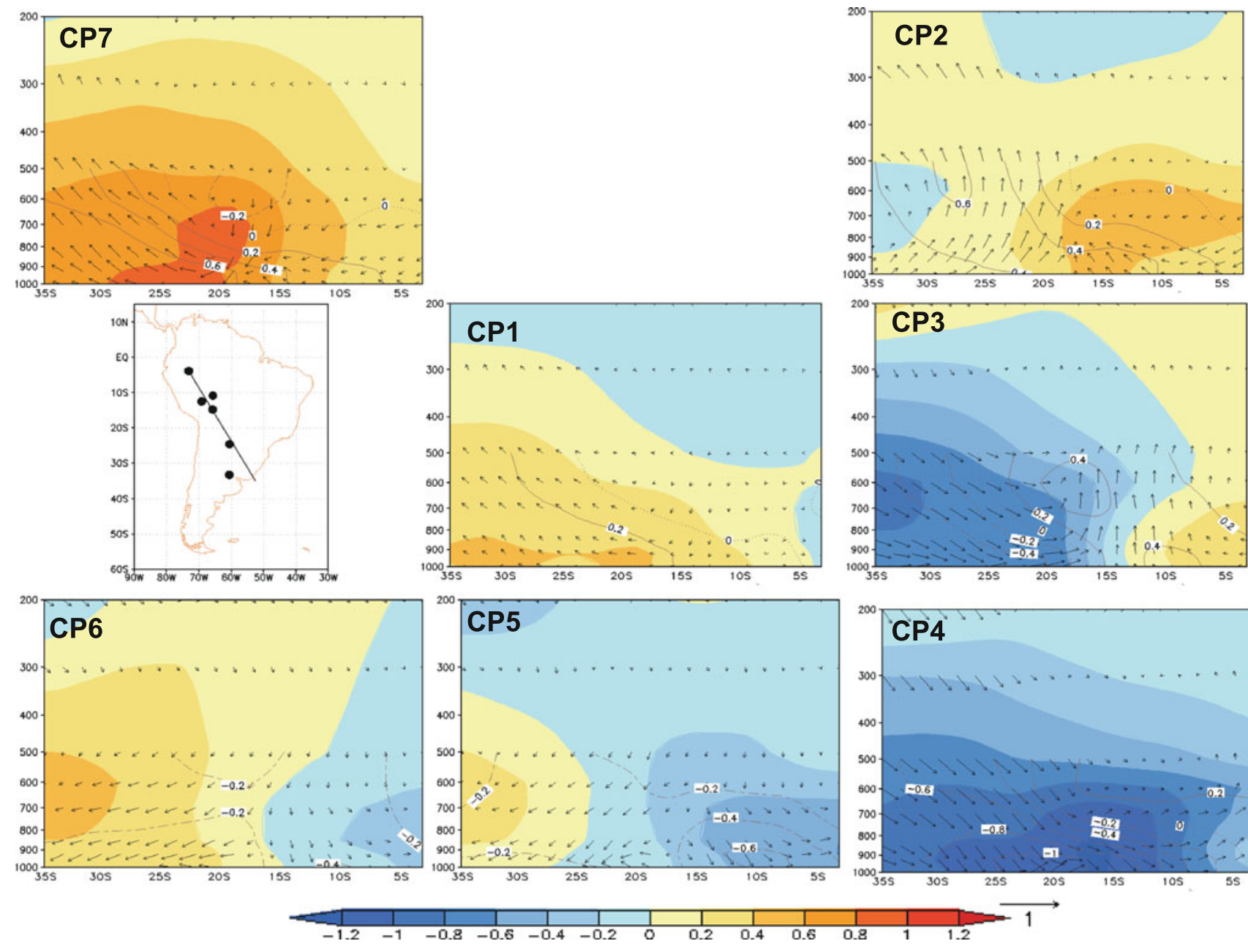

Fig. 6 Vertical structure of the atmosphere between 1,000 and $200 \mathrm{hPa}$ for the $73.25^{\circ} \mathrm{W}-3.71^{\circ} \mathrm{S}$ and $52.5^{\circ} \mathrm{W}-35^{\circ} \mathrm{S}$ section (black line in the South America map). Subseasonal resultant winds in the

To complement the composite analysis of cold surges proposed in Sect. 3, Fig. 7 shows the frequency of CPs before and after the occurrence of an extreme cold surge in SLPB initiated at $\mathrm{D}+0$. This figure evidences a predominance of $\mathrm{CP} 7$ and $\mathrm{CP} 2$ from $\mathrm{D}-5$ and $\mathrm{D}-2$, when warm conditions prevail along the eastern flank of the Andes. CP2 largely dominates at D -1 (38\% of cases), when $\mathrm{T}_{\min }$ drop already started in SLPB and NLPB (Fig. 3a). According to the temporal evolution of $\mathrm{CPs}, \mathrm{CP} 3$ and $\mathrm{CP} 4$ are the most frequent at $\mathrm{D}+0$, representing respectively 45 and $29 \%$ of the cases. These CPs are indeed characterized by southern winds and strong negative $\mathrm{T}_{\min }$ anomalies over the La Plata basin (Fig. 5b). During $D+1$, when extreme $T_{\min }$ is observed in NLPB, CP4 is the circulation pattern the most commonly observed ( $40 \%$ of the cases), while at D +2 , when the extreme $\mathrm{T}_{\text {min }}$ predominates in Bolivian Amazon and southern Peruvian Amazon, three CPs predominantly occur (CP4-18\%, CP5-17\% and CP6-22\%). During

section (black vector), temperature (colour), and specific humidity (lines) anomalies normalized at each grid-point by their standard deviation, associated with each $\mathrm{CP}$

these CPs, cold conditions prevail in the southern Amazon (CP4) and on the entire western Amazon (CP5 and CP6; Fig. 5b). At D $+3, D+4$ and D +5 , when cold conditions have propagated toward the North of Peruvian Amazon, the atmospheric circulation is characterized by CP6 (in more than $20 \%$ of the cases). Indeed, CP6 displays a strong persistence (Fig. 5a) and is characterized by cold conditions over the northwestern Amazon (Fig. 5b).

These results illustrate the consistency between the days of the composite analysis, the temporal evolution of CPs and their association to northward progression of cold surges on the eastern flank of the Andes. Moreover, it is important to note that the beginning of cold surges (composites at $\mathrm{D}-1, \mathrm{D}+0$ and $\mathrm{D}+1)$ are characterized by only one $\mathrm{CP}(\mathrm{CP} 2, \mathrm{CP} 3$ and $\mathrm{CP} 4$, respectively, in around 35-45\% of cases), while the more persistent CPs, CP7 and CP6 (Fig. 5a), are predominant from $\mathrm{D}-5$ to $\mathrm{D}-3$ and from $\mathrm{D}+2$ to $\mathrm{D}+5$, respectively (Fig. 7). 


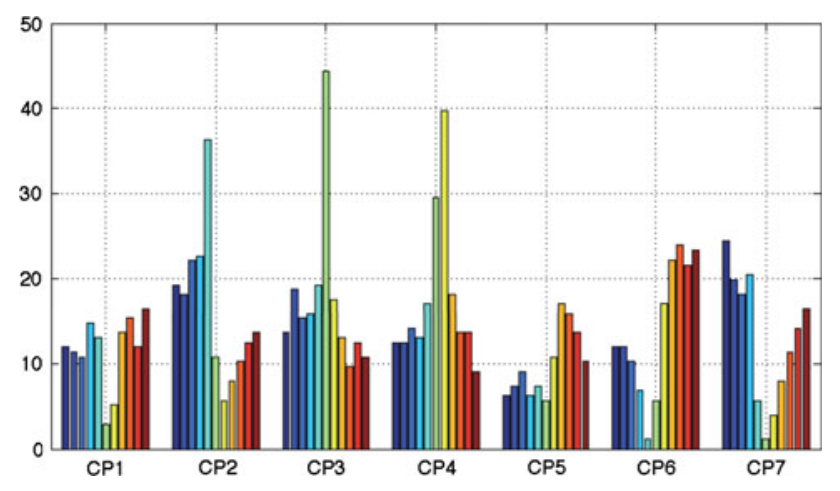

Fig. 7 Frequency of CPs (in \%) corresponding to the 11 days composites of Fig. 3a, from D - 5 (dark-blue bar), to D +0 (green bar), the first day when $\mathrm{T}_{\min }$ is below the 10th percentile in SLPB, and $\mathrm{D}+5$ (red bar)

\section{Cold surges specificities in the western Amazon}

In this section, we aim at describing the specificities in atmospheric circulation for purely tropical cold surges, i.e. those reported in the northern Amazon Basin but not in La Plata Basin during the preceding days and at comparing the atmospheric characteristics of cold surges reported in La Plata Basin that propagate or do not propagate towards the northern Amazon basin.

As described in Sects. 3, $68 \%$ of cold surges occurring in NPE were also monitored in SLPB during the five preceding days while $32 \%$ are not precedent by cold surges in the south (Fig. 3b). To better understand whether cold surges reported only in NPE are related to specific dynamics and CPs, we project separately the corresponding groups of days on the Kohonen map (Fig. 8). Cases with cold events defined in NPE preceded by cold conditions in SLPB (68\%) are related to CP6 and to a lesser extent to CP5 and CP4 (at the bottom left corner of the Kohonen map, Fig. 8a, c). However, the remaining $32 \%$, corresponding to cold events not reported further south, are not related to any specific CPs (Fig. 8b, d), i.e. these days are scattered over the entire Kohonen map. This results suggest that $32 \%$ of the cold events reported in NPE arise from different atmospheric conditions than those characteristic of cold surges, as very clear nocturnal sky, which can produce a drop of 2 or $3{ }^{\circ} \mathrm{C}$ in $\mathrm{T}_{\text {min }}$ (corresponding to a very weak amplitude between the 50th $\left(21^{\circ} \mathrm{C}\right)$ and 10 th $\left(19^{\circ} \mathrm{C}\right.$ ) percentiles of $\mathrm{T}_{\min }$ (Fig. 2, Table 1).

Differences in the atmospheric circulation for cold surges reported in La Plata basin that propagates or not towards the northern Amazon region are analysed through composite analysis of $850 \mathrm{hPa}$ wind, geopotential height and $2 \mathrm{~m}$ minimum temperature values during the $\mathrm{D}-2$ to $\mathrm{D}+3$ period for (1) cold surges that propagate from SLPB to NPE (hereafter $\mathrm{S}+\mathrm{N}$ cases, $52 \%$ of cold days in SLPB), and (2) cold surges reported only in SLPB and that do not propagate to NPE (hereafter $\mathrm{S}-\mathrm{N}$ cases, $48 \%$ of cold days in SLPB). Figure 9 displays the dynamics of all cold events reported in the South $(\mathrm{S}+\mathrm{N}$ and $\mathrm{S}-\mathrm{N}$ cases), as a reference, and the differences between $\mathrm{S}+\mathrm{N}$ and $\mathrm{S}-\mathrm{N}$ cases. As described in Sect. 3, D 0
Fig. 8 Percentage of extreme $\mathrm{T}_{\min }$ days projected onto each neuron of the Kohonen map in the NPE for a cold surges related to SLPB (68\% of cases) and $\mathbf{b}$ cold surges independent from SLPB (32\% of cases). Percentage of extreme $\mathrm{T}_{\text {min }}$ days associated to each $\mathrm{CP}$ for $\mathbf{c}$ cold surges related to SLPB (68\% of cases) and $\mathbf{d}$ cold surges independent from SLPB (32\% of cases)

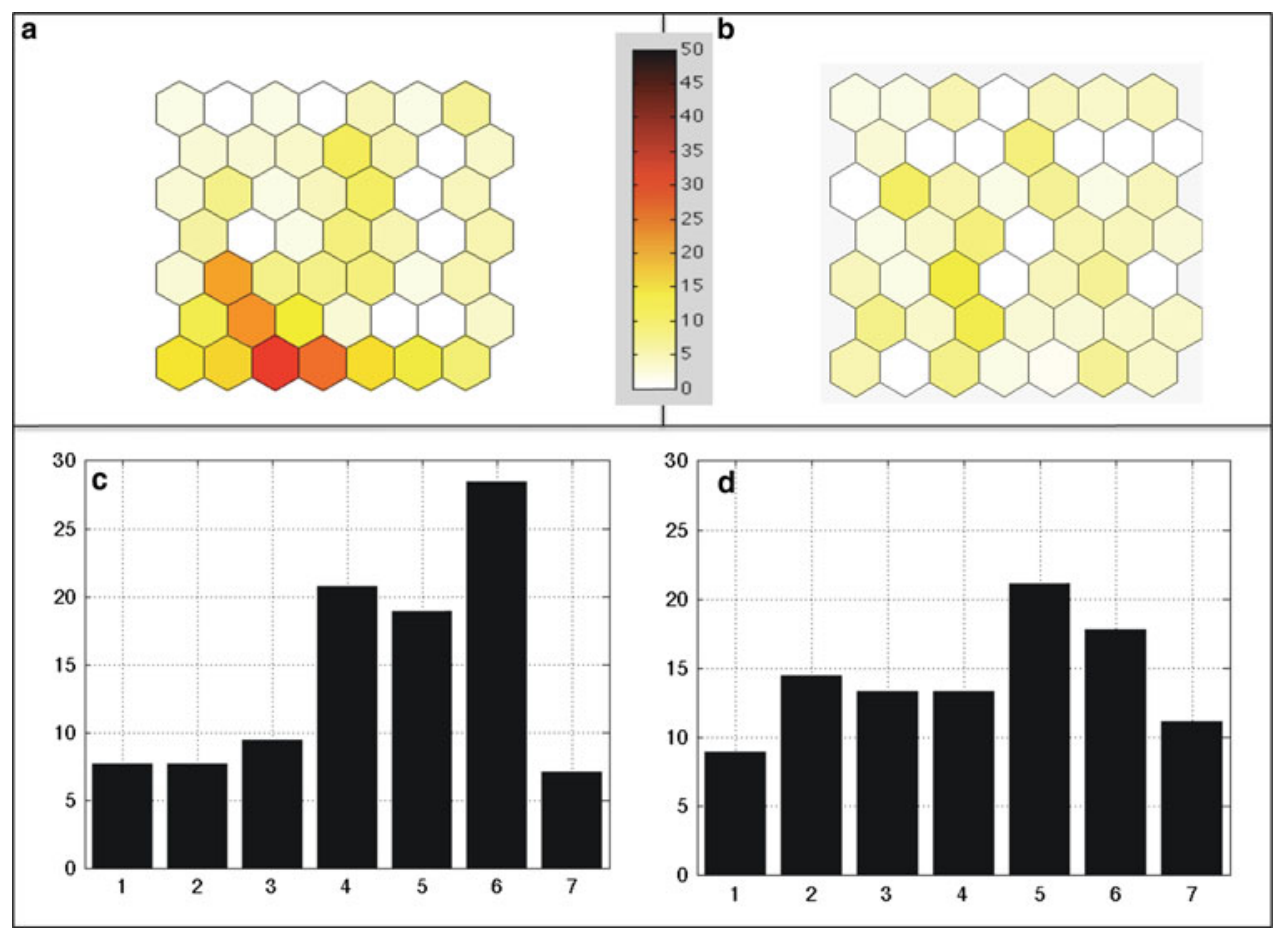


corresponds to the first day when $\mathrm{T}_{\min }$ drops below the 10th percentile in SLPB. During $\mathrm{D}-2$ to $\mathrm{D}+3$, the main differences between $\mathrm{S}+\mathrm{N}$ and $\mathrm{S}-\mathrm{N}$ cases are characterized by a positive geopotential height anomaly over the continent, which progress northward from $35^{\circ} \mathrm{S}(\mathrm{D}-2)$ to the equatorial region $(D+3)$. Over the Pacific and Atlantic oceans, mid-latitude positive geopotential anomalies intensify and move eastward, corresponding to a Rossby wave signal. These anomalies are stronger over the southern Atlantic at D -1 and $\mathrm{D}+0$ corresponding to a major cyclogenesis in the $\mathrm{S}-\mathrm{N}$ cases that deviates the southern winds eastward (Fig. 9). In contrast, for $\mathrm{S}+\mathrm{N}$ cases, the southern winds keep their northward component and progress toward the equator guided by the eastward Rossby wave propagation (Espinoza et al. 2012). Consequently, cold conditions propagate from the tropics to the equator, while the main cold core remains over $20^{\circ} \mathrm{S}$ (Fig. 9). Figure 10 further illustrates that CPs frequencies

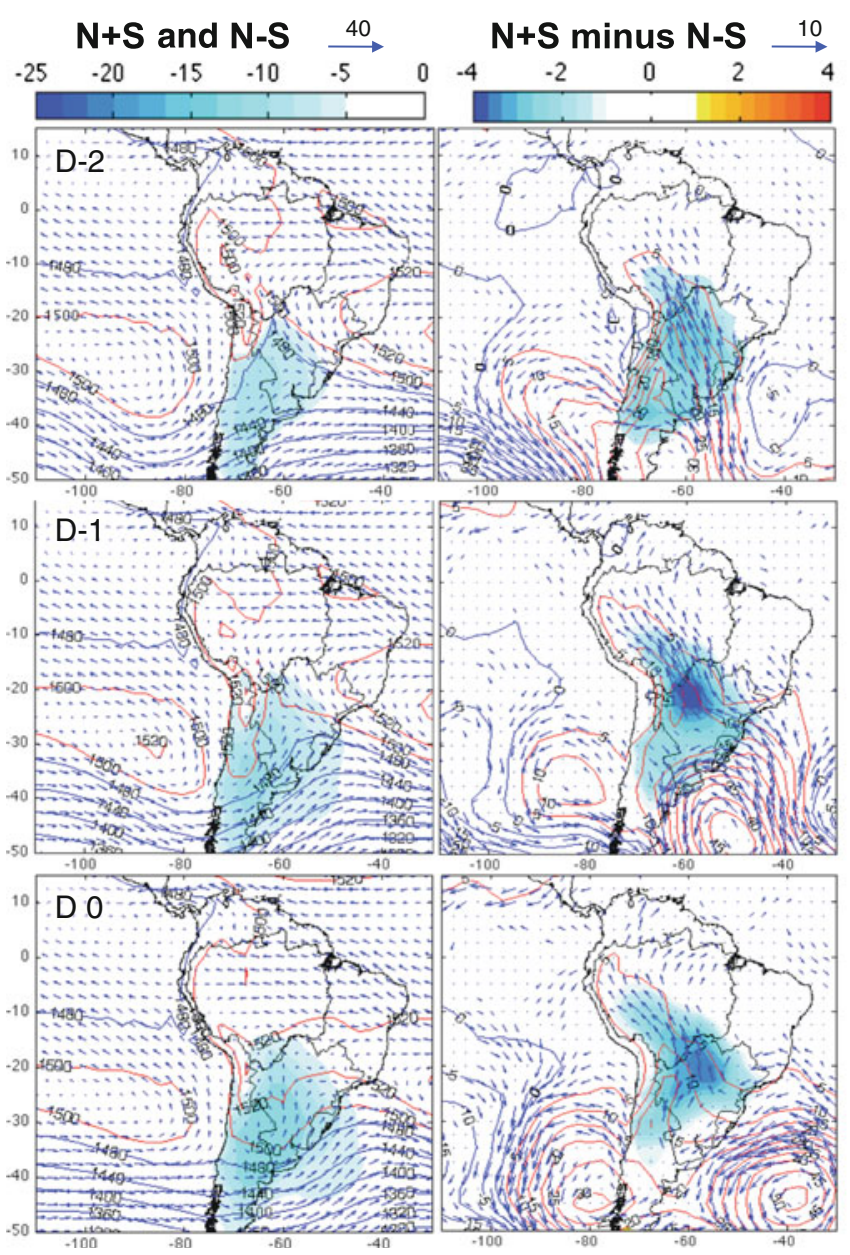

Fig. 9 Composites of $2 \mathrm{~m}$ minimal temperature (shading, ${ }^{\circ} \mathrm{C}$ ), wind (vectors, $\mathrm{m} \mathrm{s}^{-1}$ ) and geopotential height (contours, m) at $850 \mathrm{hPa}$ during $\mathrm{D}-2$ to $\mathrm{D}+3$ for (left) both $\mathrm{S}+\mathrm{N}$ (cold surges that propagate from SLPB to NPE) and S - N (cold surges reported only differ between $\mathrm{S}+\mathrm{N}$ and $\mathrm{S}-\mathrm{N}$ cases, the frequency of $\mathrm{CP} 4$ being significantly higher during the $\mathrm{S}+\mathrm{N}$ cases in $\mathrm{D}-1$ and $\mathrm{D}+1$. Cold conditions propagating northward towards the tropical regions are hence related to a higher occurrence of $\mathrm{CP} 4$, characterized by southern winds propagation in the Amazon region (Fig. 5b). This higher occurrence of $\mathrm{CP} 4$ in the days preceding the appearance of cold conditions in the tropics can be considered as a precursor of cold tropical cold surges.

For $\mathrm{S}+\mathrm{N}$ cold events, it takes about 2 days for the surge to travel the $3,500 \mathrm{~km}$ from SLPB to NPE, corresponding to a northward propagation speed of $20 \mathrm{~m} \mathrm{~s}^{-1}$. This value is larger than the equatorward wind propagation speed during summertime, estimated to be $\sim 10 \mathrm{~m} \mathrm{~s}^{-1}$ by Garreaud and Wallace (1998) and Seluchi et al. (2006), but comparable to the low-level jet speed at $850 \mathrm{hPa}$ during wintertime, estimated by Wang and $\mathrm{Fu}$ (2004).

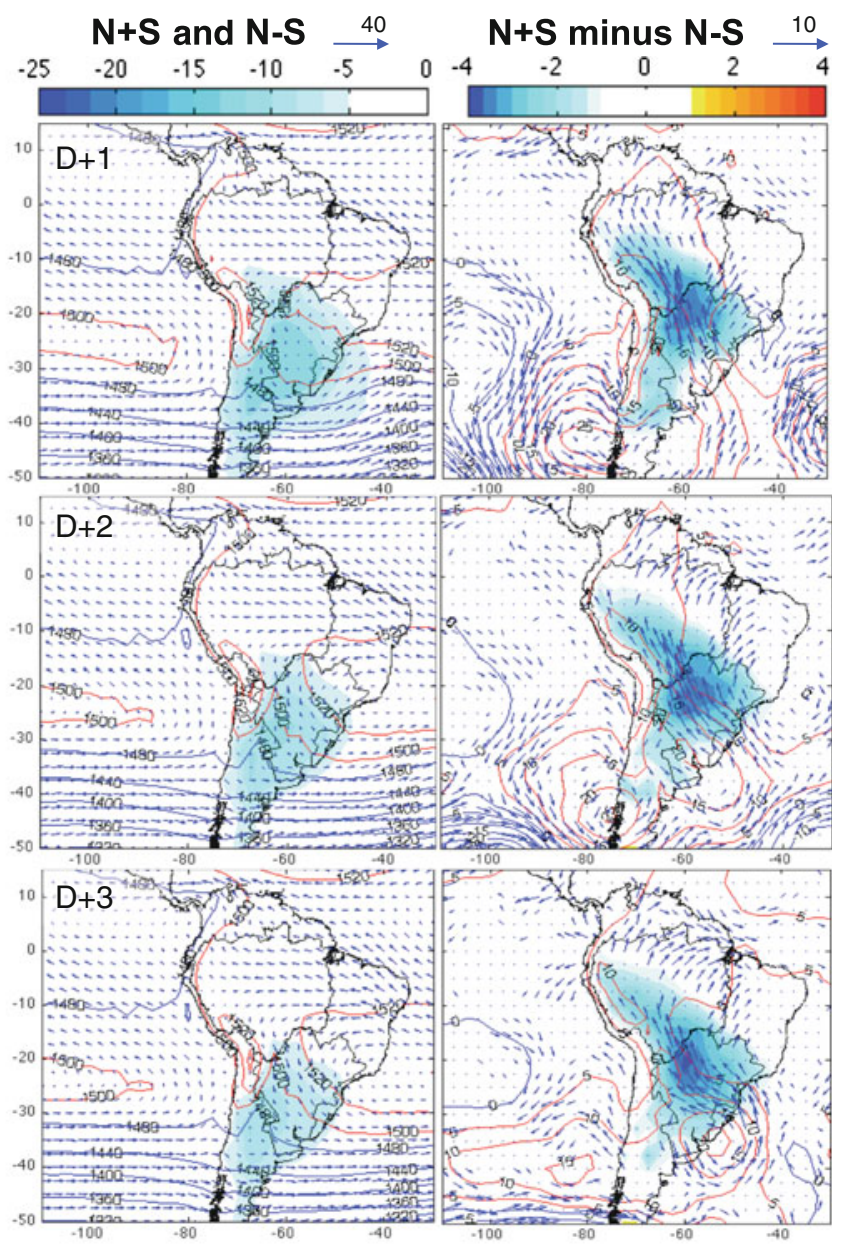

in SLPB and that do not propagate to NPE) cases and (right) $\mathrm{S}+\mathrm{N}$ minus $\mathrm{S}-\mathrm{N}$. Only wind differences higher than $0.3 \mathrm{~m} \mathrm{~s}^{-1}$ are plotted in the right panels 


\section{Cases of study of extremes cold surges in Peruvian Amazon}

This section is dedicated to the analysis of two extreme cold surges that occurred in the tropical region east of the Andes in July 1988 and July 2000. These events are known to be the most severe cold surges that reached the Peruvian and Bolivian Amazon in the last 20 years (e.g. Flores 2001; Quispe 2005, 2010). This study provides a description of the temporal evolution of cold surges based on in situ $\mathrm{T}_{\min }$ observations, their related large-scale circulation patterns (CPs) and the corresponding atmospheric conditions at $850 \mathrm{hPa}$ and at high and low level, at $35^{\circ} \mathrm{S}$ where cyclogenesis generally occurs (Seluchi et al. 2001; Vera and Vigliarolo 2000).

\subsection{A long lasting cold surge in July 1988}

An intense and long-standing cold event has been reported in tropical South America during July 1988. As shown on Fig. 11, this event is characterized by $\mathrm{T}_{\min }$ below $15{ }^{\circ} \mathrm{C}$ for 2 weeks (including 2 days below $10^{\circ} \mathrm{C}$ ) in the Bolivian Amazon. In this region, the cold episode initiates July the 5 th in the southernmost stations. Coldest temperatures are reported the 14 th July $\left(7-10{ }^{\circ} \mathrm{C}\right.$, depending on the station) with a local minimum the 8 th July $\left(10-12^{\circ} \mathrm{C}\right)$. The total temperature drop ranges from 10 to $12^{\circ} \mathrm{C}$ in SBO, NBO and SPE (Fig. 11). In NPE, the drop starts 1-day later, the 6th July. The temperature decreases from 22 to $17^{\circ} \mathrm{C}$ the 14th July. As expected, this cold episode in the tropics is associated with a severe cold surge in the subtropics. SLPB and NLPB minimum temperature drops respectively by $16{ }^{\circ} \mathrm{C}$ in 5 days and $23{ }^{\circ} \mathrm{C}$ in 8 days between the 1 st and the 8th July 1988. Then, SLPB and NLPB minimum temperatures remain respectively close to $-5{ }^{\circ} \mathrm{C}$ during 8 days (from the 5 th to the 12 th) and close to $0{ }^{\circ} \mathrm{C}$ during 7 days (from the 7th to the 13th). Referring to Fig. 3c, this duration is exceptionally long. Finally, from the 13 th, $T_{\min }$ starts increasing in SLPB and NLPB.

In the tropical stations, $\mathrm{CP} 2$ conditions characterize the atmospheric circulation until the 6th. Then, alternating CP3 and CP4 conditions favour varying $\mathrm{T}_{\min }$. The occurrence of CP6 then induces the important temperature drop in tropical regions and results in the reestablishment of northern warm winds in the La Plata region.

The main features of the dynamics of the atmosphere during this event can be further described using longitudetime Hovmöeller $200 \mathrm{hPa}$ and $925 \mathrm{hPa}$ diagrams at $35^{\circ} \mathrm{S}$ (Fig. 12) and spatial maps of the low-level circulation (Fig. 13). From the 2nd to 6th of July, during the initiation phase of the cold surge, a cyclonic circulation at $200 \mathrm{hPa}$ develops in the subtropical Pacific $\left(35^{\circ} \mathrm{S} ; 70-90^{\circ} \mathrm{W}\right)$, with geopotential height as low as $11340 \mathrm{~m}$ between $70^{\circ} \mathrm{W}$ and
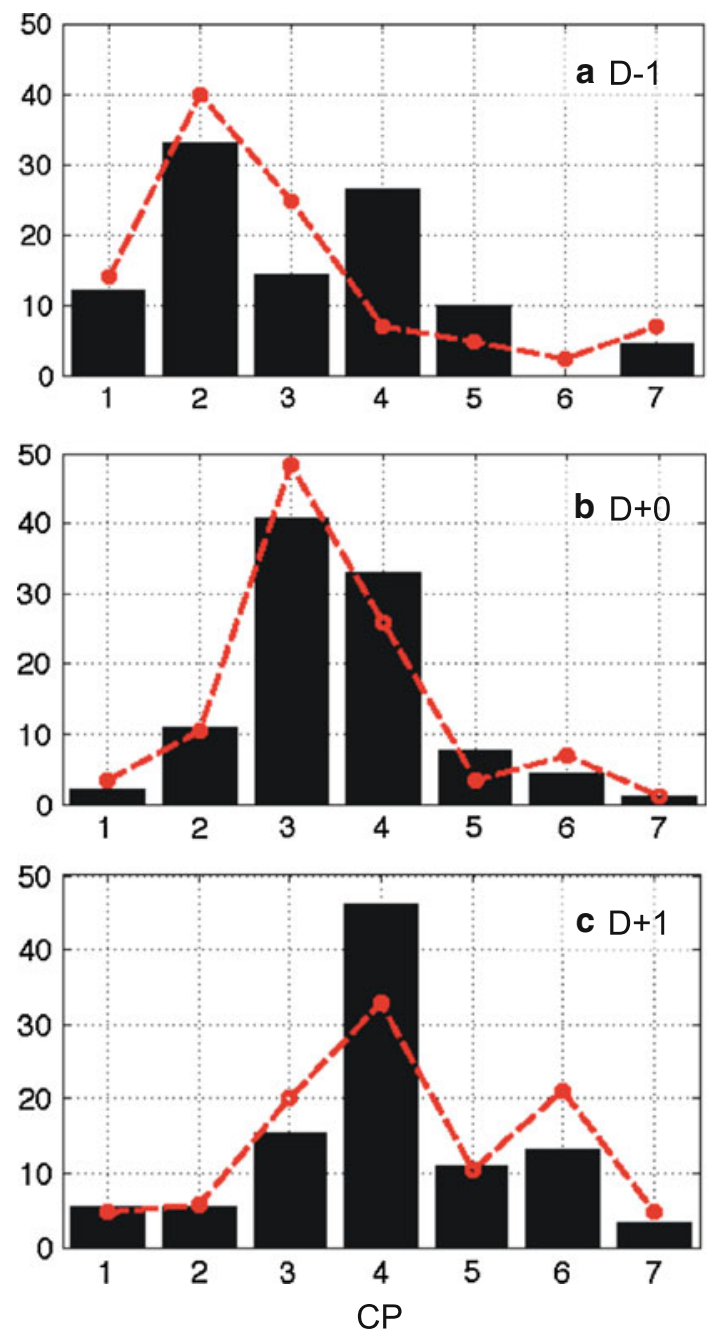

Fig. 10 Frequency (in \%) of CPs for a D $-1, \mathbf{b} \mathrm{D}+0$ and c $\mathrm{D}+1$, considering (black bars) cold surges that propagate from SLPB to NPE ( $\mathrm{S}+\mathrm{N}$ cases) and (red line) cold surges reported only in SLPB and that do not propagate to NPE ( $\mathrm{S}-\mathrm{N}$ cases). $\mathrm{D}+0$ is the first day with $\mathrm{T}_{\text {min }}$ below the 10th percentile in SLPB

$80^{\circ} \mathrm{W}$ (Fig. 12a), and southwestern winds on the western flank of the trough. In contrast, a high geopotentiel height is observed over the Atlantic. The eastern flank of the through displays an eastward moving negative advection of vorticity (blue colour on Fig. 12a), characteristic of a trough-ridge couplet (e.g. Lupo et al. 2001). Vera and Vigliarolo (2000) show that the upper level cyclonic perturbation is associated with a displacement of the subtropical jet further north over South America, which favours the subsidence near the surface, related to an equatorward displacement of the descending branch of the Hadley type cell (which in turn facilitates the propagation of the frontal system towards the tropics). This system favours the formation of an anticyclone near the surface (Seluchi et al. 2001). In fact, near the ground, a positive and strong pressure centre is noticed in the South Pacific (at 
$80^{\circ} \mathrm{W}$ ), which progresses eastward over the continent from July 6th (Figs. 12b, 13). The South Atlantic is characterized by a low-pressure centre near the surface. These features are coherent with $\mathrm{CP} 2$, which characterizes the atmospheric circulation from the 4th to 6th July, at the beginning of the cold episode (Figs. 11, 13).

From July 7th, the trough-ridge couplet at $200 \mathrm{hPa}$ progresses eastward, generating a system of negative vorticity advection on the Atlantic and positive vorticity advection over the continent (Fig. 12a). This system however weakens July 8th and 9th producing eastward winds over the continent at $200 \mathrm{hPa}$. During this period, an abrupt pressure decrease occurs over the Atlantic, from 1,020 to $1,008 \mathrm{hPa}$, which contributes to the interruption of southern winds and to the setting of temporary western winds. It results in a pause of the cold air advection and a slight warming (Fig. 11) and corresponds to alternating CP3 and CP4 conditions. From July 10th, the positive vorticity advection at $200 \mathrm{hPa}$ is reinforced over the continent favouring southwestern winds (Fig. 12a). These features in the high troposphere reinforce the anticyclogenesis on the continent near the surface, producing a
Fig. $11 \mathrm{~T}_{\min }$ at the virtual stations during the 1 st to 20 th July 1988 period. The CPs associated with these days are indicated (gray shaded). Points indicate the 10th percentile of $\mathrm{T}_{\min }$ for each virtual station

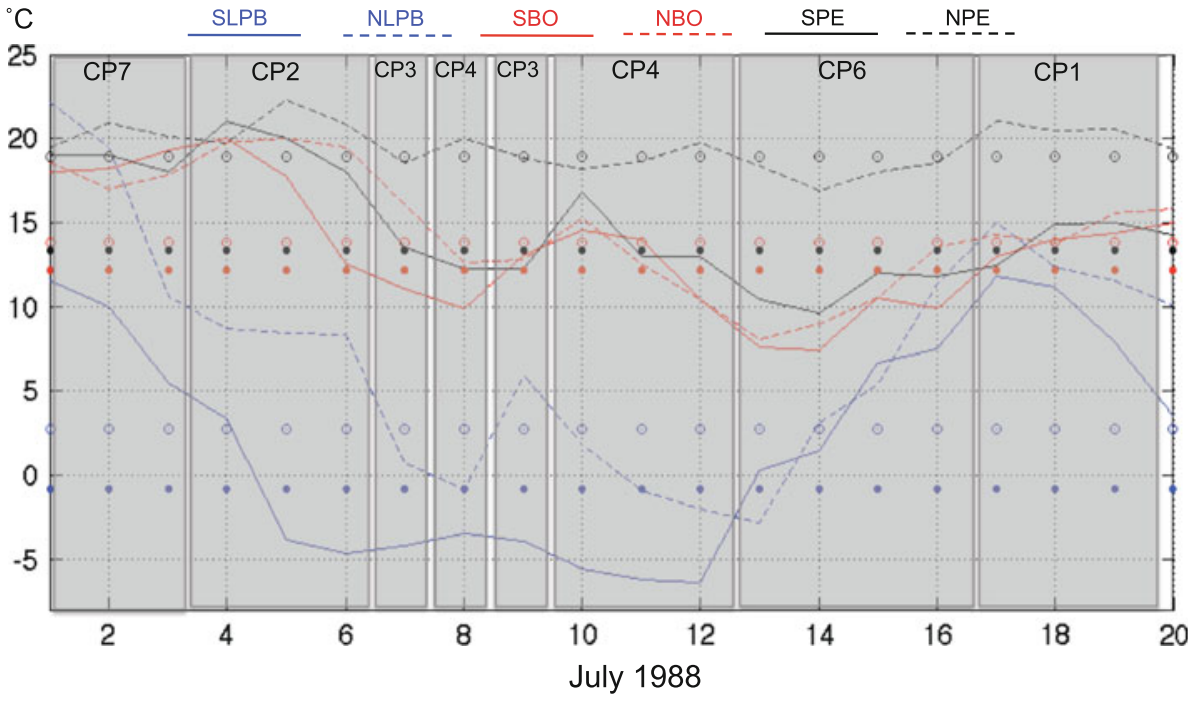

Fig. 12 Hovmöeller diagram for a W-E section at $35^{\circ} \mathrm{S}$ section, for the 1st to 15th July 1988 period. Black lines represent the South American coast at $35^{\circ} \mathrm{S}$. The dynamic of the atmosphere is described at a) $200 \mathrm{hPa}$, using horizontal advection of vorticity $\left(\mathrm{s}^{-2} \times 10^{9}\right.$,

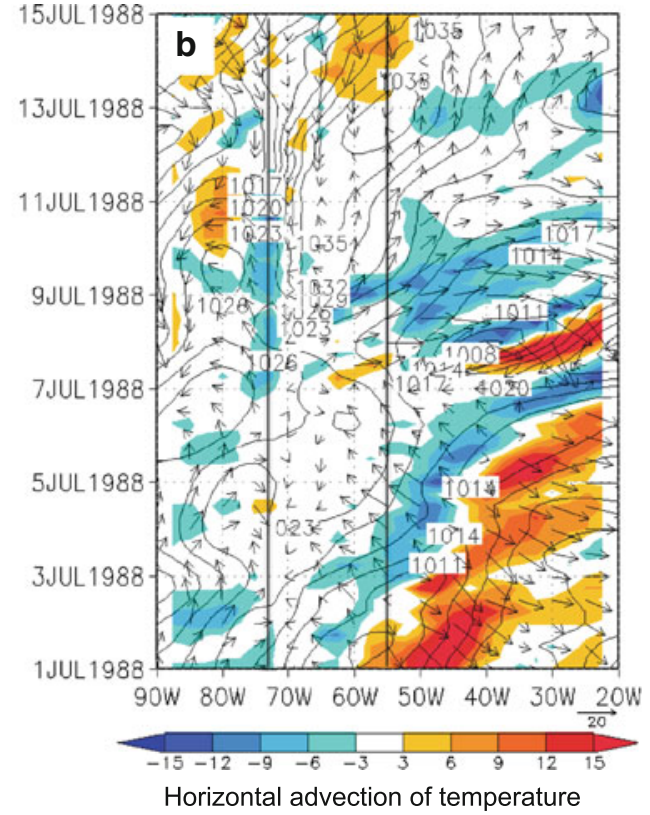

colours), geopotential height ( $\mathrm{m}$, lines) and total wind $\left(\mathrm{m} \mathrm{s}^{-1}\right.$, vectors), and at b $925 \mathrm{hPa}$, using horizontal advection of temperature $\left({ }^{\circ} \mathrm{C}\right.$ day $^{-1}$, colours), pressure reduced to sea level (hPa, lines) and total wind $\left(\mathrm{m} \mathrm{s}^{-1}\right.$, vectors $)$. Figures use ERA-40 Reanalysis data 
centre of high pressure $(1,038 \mathrm{hPa})$ July 12 th and 13 th at $55^{\circ} \mathrm{W}$ (Fig. 13), while a centre of lower pressure $\left(1,017 \mathrm{hPa} ; 20^{\circ} \mathrm{W}\right)$ is observed over the Southern Atlantic (Fig. 12b). This pattern reinforces the gradient of pressure between the continent and the ocean, from July 9th to 15th and, consequently, resulting in southern wind intrusions and cold anomalies over the western Amazon (Fig. 13), corresponding to $\mathrm{CP} 4$ and latter on to $\mathrm{CP} 6$ conditions. The southern winds reach up to $15 \mathrm{~m} \mathrm{~s}^{-1}$ over the continent during these days (Fig. 12b). During this case of study, CP2 and CP4 are persistent, which is coherent with the high frequency of CP4 during the cold surges in the south that propagate toward north (i.e. $\mathrm{N}+\mathrm{S}$ cases, see Sect. 6 and Fig. 10).

\subsection{An abrupt cold surge in July 2000}

A sudden $\mathrm{T}_{\min }$ decrease, especially over the tropical region, has been reported between the 10th and 12th of July 2000 (Fig. 14): the temperature drops by $12{ }^{\circ} \mathrm{C}$ in 2 days in the Bolivian stations. $\mathrm{T}_{\min }$ as low as $8{ }^{\circ} \mathrm{C}$ in $\mathrm{SBO}$ and in Puerto Maldonado (southern Peru, Flores 2001) and $10{ }^{\circ} \mathrm{C}$ in NBO are registered under $\mathrm{CP} 4$ conditions. In NPE, the lowest temperature is reported 2 days latter during CP6 with a weaker temperature drop $\left(\sim 6^{\circ} \mathrm{C}\right)$. In La Plata basin, an intense and long lasting drop in temperature (a week of frost) and $\mathrm{T}_{\min }$ as low as $-5{ }^{\circ} \mathrm{C}$ in NLBP began 2 days sooner than in Bolivia. It is noticeable that this strong event has been preceded by a previous cold episode characterized by a transition from CP3 to CP6 during the 3rd to 6th July period (Fig. 14).

At $200 \mathrm{hPa}$, during the period between the 3th and 8th of July, the subtropical jet is well developed at $35^{\circ} \mathrm{S}$ and a system of negative (positive) vorticity advection on its eastern (western) side, which characterize a ridge-trough wave, moves eastward from the Pacific to the Andes Mountains (Fig. 15a). During this period a total and rapid South American circulation cycle is observed, from CP2 to CP6.

According to the intensification of this system, from July 9th to 14th, southern winds and positive vorticity advection appear in the subtropical Pacific and reach the continent July 11th, while negative vorticity conditions are observed in the south east of South America during this period. This intense ridge-trough wave produce a low geopotential height over the continent at $200 \mathrm{hPa}$ during these days (Fig. 15a). At 925 and $850 \mathrm{hPa}$, the anticyclogenesis is well developed over the continent, with a maximum of pressure $\left(1,035 \mathrm{hPa}\right.$ at $\left.67^{\circ} \mathrm{W}\right)$ between July 11 th and 12 th, accompanied by a centre of low pressure on the Atlantic, very close to the continent $\left(1,008 \mathrm{hPa}\right.$ at $47^{\circ} \mathrm{W}$; Figs. $\left.15 \mathrm{~b}, 16\right)$. These conditions enhance cold advection over La Plata
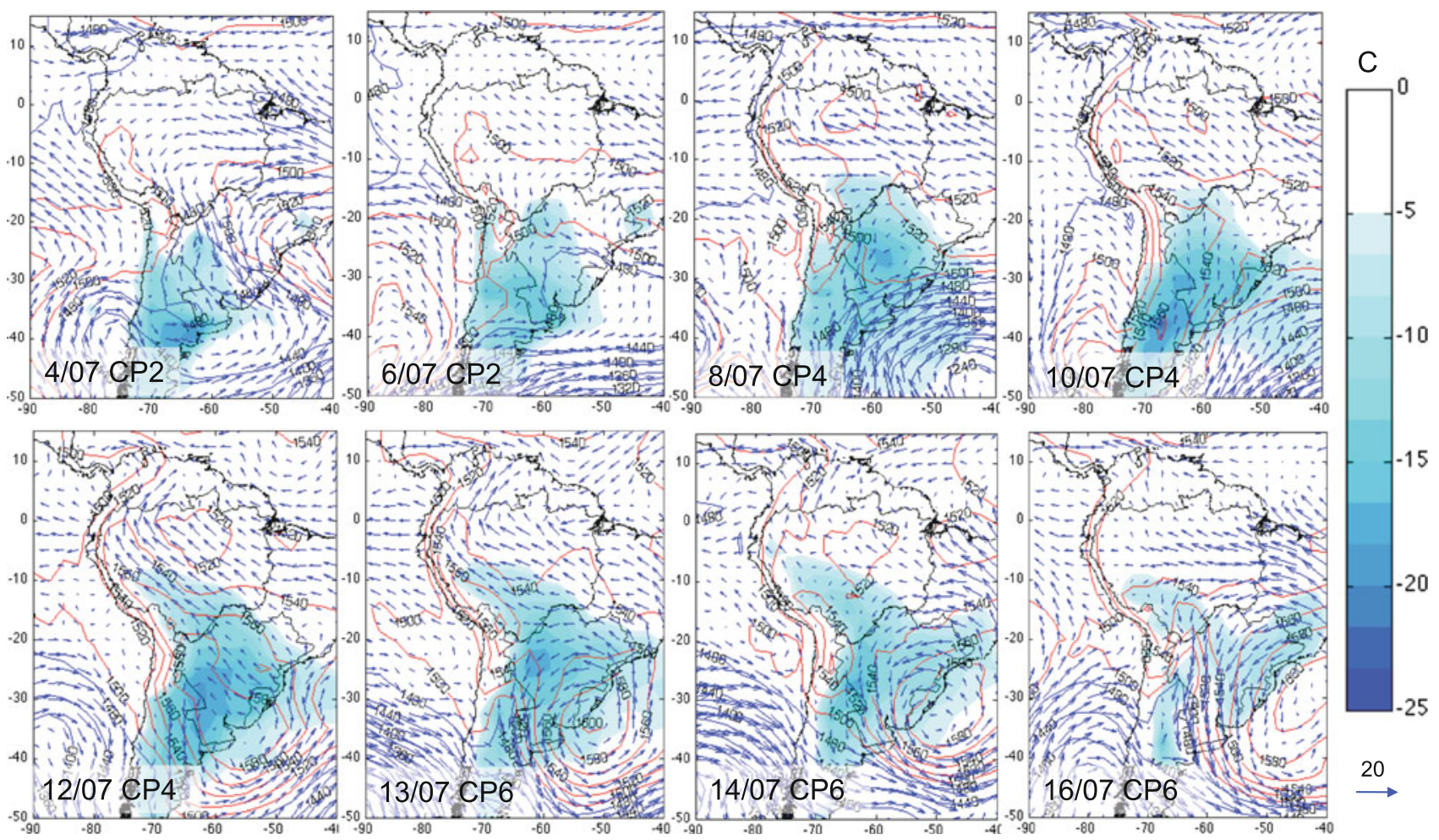

Fig. $13 \mathrm{~T}_{\min }$ anomalies at $2 \mathrm{~m}$ (shading, ${ }^{\circ} \mathrm{C}$ ), winds (vectors, $\mathrm{m} \mathrm{s}^{-1}$ ) and geopotential (contours, $\mathrm{m}$ ) at $850 \mathrm{hPa}$, for July 4th, 6th, 8th, 10th, 12-14th and 16th 1988 
Fig. $14 \mathrm{~T}_{\min }$ at the virtual stations during the 1 st to 20 th July 2000 period. The CPs associated with these days are indicated (gray shaded). Points indicate the 10th percentile for each virtual station

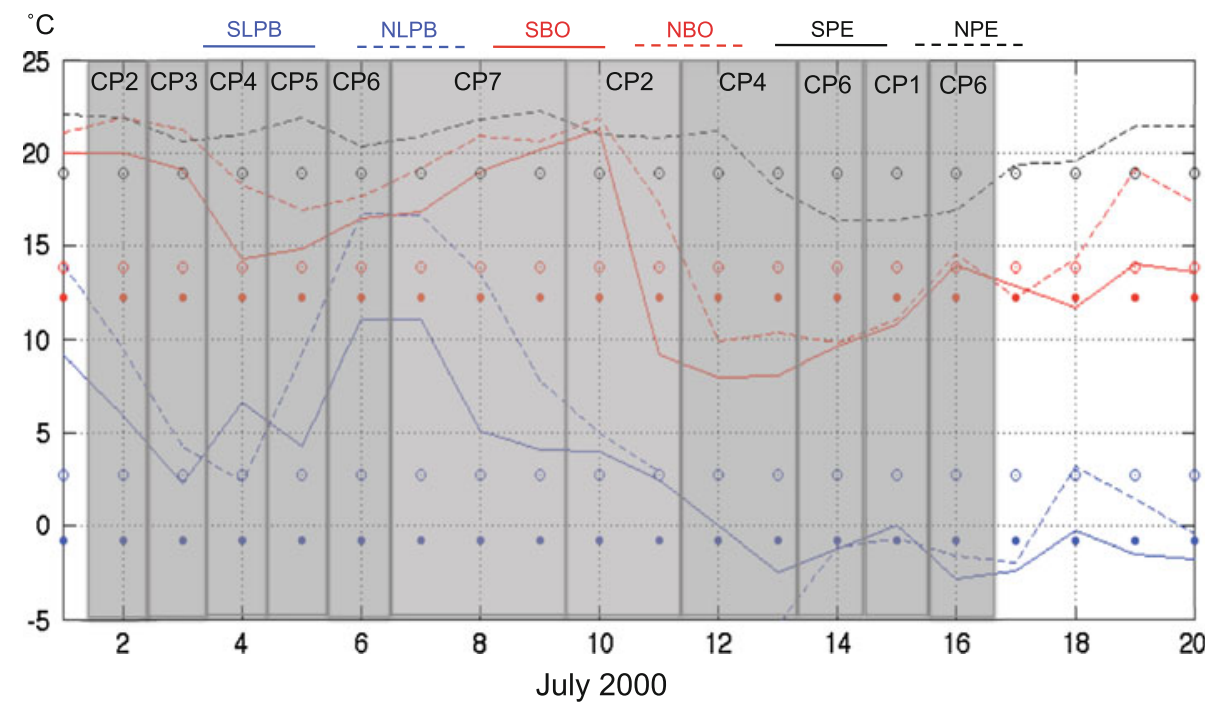

Fig. 15 As Fig. 11, but for the 1 st to 15 th July 2000 period

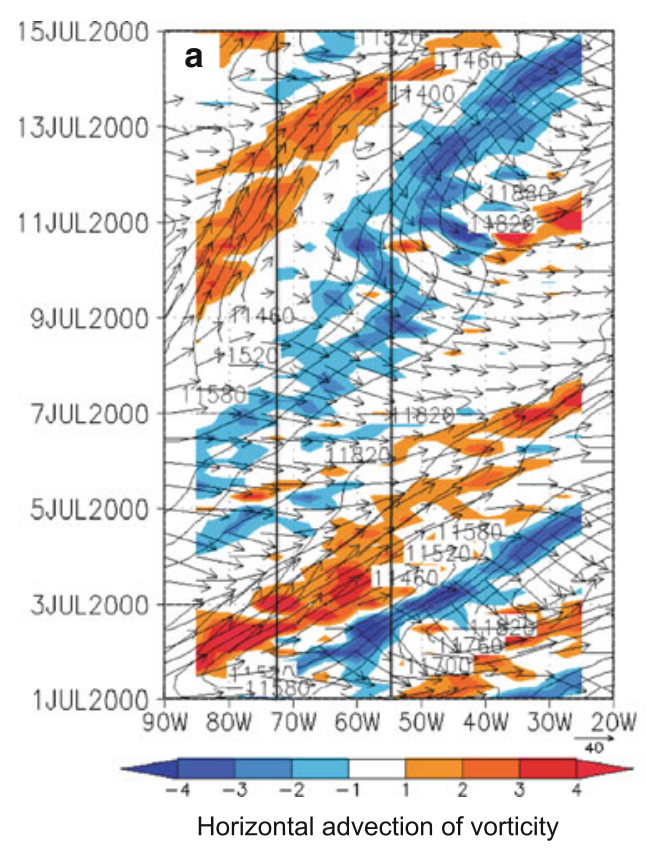

basin and the extreme south of Amazon region from the 10th to 12 th (Fig. 16). These features result in a large pressure gradient between $67^{\circ} \mathrm{W}$ and $47^{\circ} \mathrm{W}$ during July 10th to 14 th, which in turn favours a strong southern winds incursion reaching up to $20 \mathrm{~m} \mathrm{~s}^{-1}$ (Fig. 15b). The atmospheric conditions of July 10th and 11th are typical of CP2 characterizes, while the following 2 days belong to $\mathrm{CP} 4$. The high frequency of CP4 during this particular event is coherent with what has been observed during the $\mathrm{N}+\mathrm{S}$ cases (see Sect. 6 and Fig. 10). The strong geopotential gradient observed in the low troposphere during these days (Figs. 15b, 16) is responsible for the exceptional situation described above, with a direct transition from $\mathrm{CP} 2$ to $\mathrm{CP} 4$, hence explaining the very abrupt temperature drop in Bolivia. The transition from CP2 to CP3 is indeed the most frequent, i.e. in more than $30 \%$ of cases (Fig. 5a), while the unusual transition from $\mathrm{CP} 2$ to $\mathrm{CP} 4$ only occurs in $3 \%$ of the cases. Indeed, intense southern winds and positive geopotential anomalies are observed over this region (Fig. 16), resulting in a cold incursion over western Amazon since the July 12 th.

Among the main dynamical differences between the two case studies, we can note a deep ridge over the continent between July 9th and 11th 2,000 at $200 \mathrm{hPa}$, which is accompanied by very weak winds near its concavity (Fig. 15a). These conditions favour a powerful vorticity 


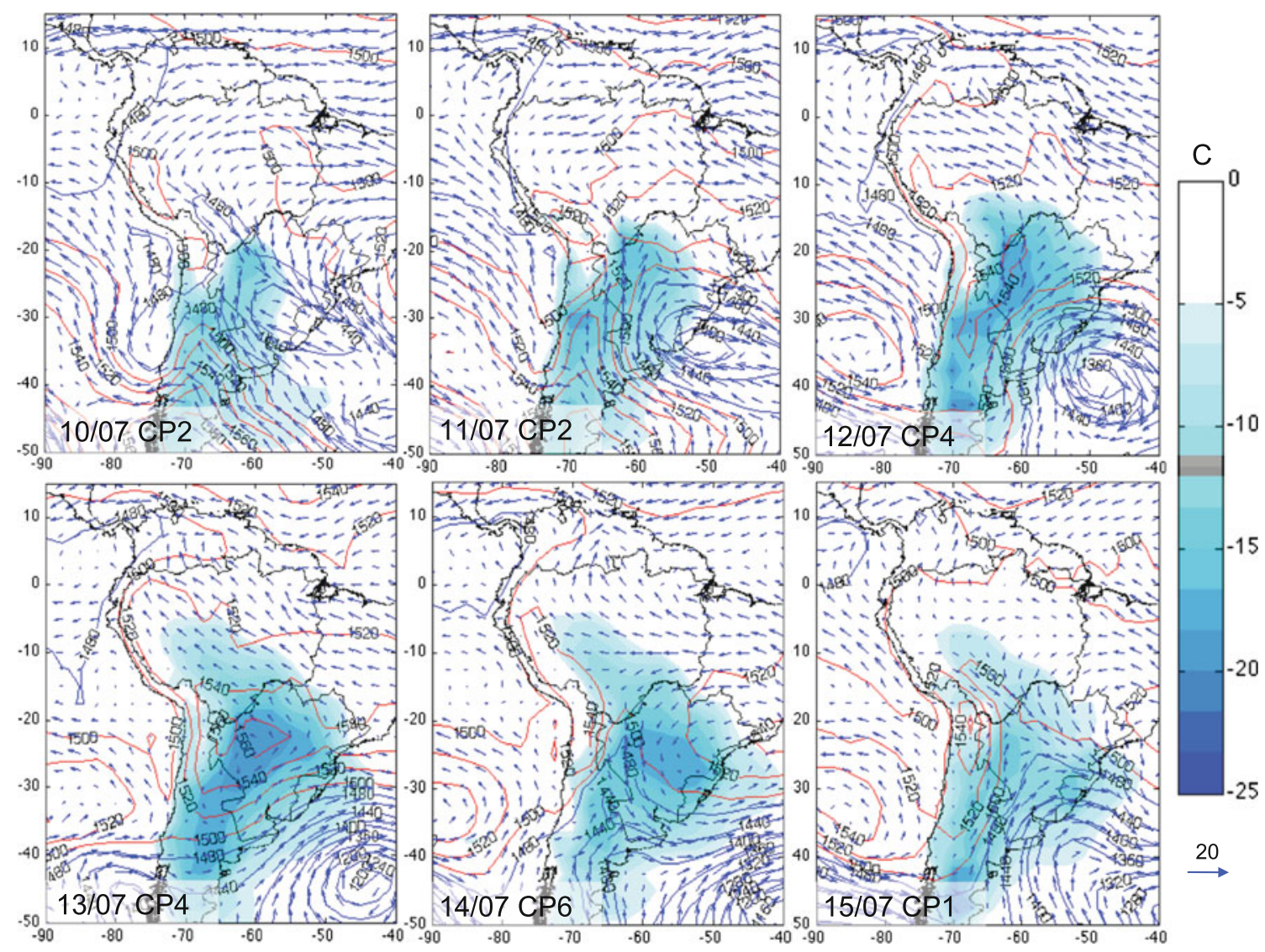

Fig. 16 As Fig. 12 but from July 10th to July 15th 2000

advection and an explosive anticyclogenesis on the continent and a low pressure on the Ocean (at $50^{\circ} \mathrm{W}$ ), producing a strong pressure gradient, intense southern winds and a very abrupt decrease in temperature in tropical regions (Fig. 16). These features are also responsible of the unusual and direct transition from CP2 to CP4 between July 11th and 12th (Fig. 14). In July 1988, however, the ridge at $200 \mathrm{hPa}$ is weaker over the continent and reinforced on the Atlantic Ocean (between the 7th and 9th, Fig. 12a), producing a low pressure centred far from the continent (at $40^{\circ} \mathrm{W}$, Fig. 12b). In consequence, the gradient between high pressures on the continent and low pressures over the ocean is weaker, compared to the July 2000 episode, generating a more progressive cooling in the tropical region and a remission July 9th. Though, the phenomenon is much longer in 1998, lasting nearly 10 days, from July 5th to 14th (Fig. 11b).

\section{Concluding remarks}

The present study describes the mean characteristics of winter cold surges along the eastern flank of the Andes using in situ temperature from Argentina, Bolivia and Peru and ERA-40 reanalysis data over the 1975-2001 period. The main objectives of this work are threefold: (1) describe the propagation of cold surges from extra-tropical South America to the northwestern Amazon region; (2) identify the large-scale circulation patterns at intraseasonal timescale (CPs) associated with cold surges in southern and tropical South America, paying particular attention to the atmospheric forcing that favour the effective penetration of cold intrusions in western Amazon and (3) analyze the dynamics of the atmosphere during two cases of severe cold intrusions in the tropical regions at the east of the Andes.

Cold days are identified when daily minimum temperature $\left(T_{\min }\right)$ undergoes the 10th percentile of climatological $\mathrm{T}_{\min }$ at a given location. This threshold corresponds to temperature of $-0.8{ }^{\circ} \mathrm{C}$ in the southern La Plata basin, $2.7^{\circ} \mathrm{C}$ in the northern La Plata basin, 12.2 and $13.8^{\circ} \mathrm{C}$ in the southern and northern Bolivian Amazon and 13.5 and $18.9^{\circ} \mathrm{C}$ in southern and northern Peruvian Amazon, respectively. In winter, highest $\mathrm{T}_{\min }$ (around $20-25^{\circ} \mathrm{C}$ ) are strikingly similar in all stations while lowest values strongly differ, rapidly decreasing toward mid-latitude. Every winter, about three to four cold episodes occur in each station, with largest occurrence probability in July. 
These events usually do not last long, especially in the subtropics were $60 \%$ last only 1 day and $8 \% 3$ days. Some longer events are however reported in the tropics where $15 \%$ last 3 days. Cold surges generally propagate from the south of La Plata basin to the Bolivian Amazon and southern Peruvian Amazon in 2 days, and to the northern Peruvian Amazon in 2 or 3 days. Only the half $(52 \%)$ of cold surges originating from the subtropics reaches the equatorial regions. On another hand, only $68 \%$ of cold surges defined in northern Peruvian Amazon are previously observed in the south of the La Plata basin. Our in situ data hence reveal that cold surges that attain equatorial region move northward in 2 days by $\sim 3,500 \mathrm{~km}$, corresponding to a mean propagation speed of $20 \mathrm{~m} \mathrm{~s}^{-1}$. The northward propagation of cold surges can be related to the characteritics of 7 circulation patterns (CPs) defined by an eastward moving extra tropical Rossby waves. Our analyses suggest that cold surges move northward during four particular CPs corresponding to the northward progression of southern low-level winds. It is accompanied by a subsidence and dry conditions in the middle and low troposphere $(1,000-500 \mathrm{hPa})$ that reinforce coolness by radiative effect. Moreover, cold surges are preceded by ascendance motion and convection that also move northward along the eastern side of the Andes.

We also depict the main specificities of cold air intrusions that propagate towards the northern Peruvian Amazon. This is of particular interest as they are poorly documented in the literature, contrarily to cold events occurred in the South American subtropics. In contrast to cold surges observed in sub-tropics but not in equatorial region, cold intrusions propagating towards the tropics and equatorial region are characterized by high positive geopotential height anomalies over the continent and associated with intense southern winds anomalies that progress northward in around 5 days. Consistently, cold surges propagating towards the tropics are associated with a higher frequency of CP4 characterized by strong southern winds anomalies over La Plata and Amazon regions. As its predominance is observed before the occurrence of cold surges in the tropics, this CP can be considered as a precursor of cold events in western Amazon. Cold surges confined in the south of the continent, on the contrary, experience weaker positive pressure anomalies on the continent and negative ones over the subtropical South America and the Southern Atlantic that favour a divergence of the cold air, deflecting part of it toward the Atlantic.

To complement our study, we also detailed the atmospheric features associated with two extreme cold surges that occurred in the tropics in 1998 and 2000. Results show that different types of events can occur, according to their persistence and intensity. For instance, extreme cold event can last for a week as in July 1988 and produce a progressive drop in temperature or, on the contrary, be shorter with a very sudden abrupt drop as in July 2000. These differences (and the differences with the median cases) depend on the dynamics of the atmosphere and on different atmospheric features: the intensity of the advection of vorticity on the continent, of the southern wind and of the pressure gradient near to the surface. For instance, short and abrupt events are related to intense southern winds and large geopotential height gradient near the surface. Longer and smoother events seem to be associated with atmospheric conditions that favour more stationary cold advections. During both cases, CPs are well related to the temporal evolution of cold surge and to their equatorward progression, contributing to understand their dynamics. These indicators could be used as tools to predict the occurrence and characteristics of cold events in the tropics.

Acknowledgments The authors are grateful to the Meteorological Services from Peru (SENAMHI), Bolivia (SENAMHI) and Argentina (SMN) for the data availability. The research leading to these results has received funding from the European Community's Seventh Framework Programme (FP7/2007-2013) under Grant Agreement No. 212492: CLARIS LPB. A Europe-South America Network for Climate Change Assessment and Impact Studies in La Plata Basin.

\section{References}

Ambrizzi T, Hoskins B (1997) Stationary Rossby-wave propagation in a baroclinic atmosphere. Q J R Meteorol Soc 123:919-928

Badran F, Yacoub M, Thiria S (2004) Self-organizing maps and unsupervised classification. In: Dreyfus G (ed) Neural networks: methodology and applications. Springer, Berlin

Bettolli ML, Penalba OC, Vargas WM (2010) Synoptic weather types in the south of South America and their relationship to daily precipitation in the core production region of crops in Argentina. Aust Meteorol Oceanogr J 60:37-48

Bischoff S, Vargas W (2003) The 500 and $1000 \mathrm{hPa}$ weather circulations and their relationship with some extreme climatic conditions over southern South America. Int J Climatol 23:541-556

Compagnucci RH, Salles MA (1997) Surface pressure patterns during the year over southern South America. Int J Climatol 17:635-653

Espinoza JC, Lengaigne M, Ronchail J, Janicot S (2012) Large-scale circulation patterns and related rainfall in the Amazon Basin: a neuronal networks approach. Clim Dyn. doi:10.1007/s00382011-1010-8

Flores, S (2001). Análisis de los "friajes" en la Amazonía peruana durante el mes de julio del 2000. Revista de trabajos de investigación. CNDG-Sismología Instituto Geofísico del Perú. V.2. Lima Perú, pp 21-30

Fortune M, Kousky VE (1983) Two severe freezes in Brazil: precursors and synoptic evolution. Mon Weather Rev 111: 181-196

Garreaud RD (1999) Cold air incursions over subtropical South America: a numerical case study. Mon Weather Rev 127: 2823-2853

Garreaud RD (2000) Cold air incursions over subtropical and tropical South America: mean structure and dynamics. Mon Weather Rev 128:2544-2549 
Garreaud R, Wallace JM (1998) Summertime incursions of midlatitude air into subtropical and tropical South America. Mon Weather Rev 126:2713-2733

Garreaud RD, Vuille M, Compagnucci R, Marengo J (2009) Presentday South American climate. Palaeogeogr Palaeoclimatol Palaeoecol 281(3-4):180-195

Gueye AK, Janicot S, Niang A, Sawadogo S, Sultan B, DiongueNiang A, Thiria S (2010) Weather regimes over Senegal during the summer monsoon season using self-organizing maps and hierarchical ascendant classification. Part I: synoptic time scale. Clim Dyn. doi:10.1007/s00382-010-0782-6

Hamilton MG, Tarifa JR (1978) Synoptic aspects of a polar outbreak leading to frost in tropical Bazil, July 1972. Mon Weather Rev 106:1545-1556

Hewitson B, Crane R (2002) Self-organizing maps: applications to synoptic climatology. Clim Res 26:1315-1337

Jain AK, Dubes RC (1988) Algorithms for clustering data. Prentice Hall, Englewood Cliffs

Jones C, Carvalho LMV, Higgins RW, Waliser DE, Schemm JKE (2004) Climatology of tropical intraseasonal convective anomalies: 1979-2002. J Clim 17:523-539

Kiladis GN, Weickmann KM (1992) Circulation anomalies associated with tropical convection during northern winter. Mon Weather Rev 120:1900-1923

Kohonen T (1984) Self organization and associative memory, 2nd edn. Springer, Berlin, p 312

Kohonen T (2001) Self-organizing maps. Springer series in information sciences, 3rd edn. Springer, New York, p 30

Kousky VE (1979) Frontal influence on northeast Brazil. Mon Weather Rev 107:1140-1153

Krishnamurti TN, Tewari M, Chakraborty DR, Marengo J, Silva Dias PL, Satyamurty P (1999) Downstream amplification: a possible precursor to major freeze events over southeastern Brazil. Weather Forecast 14:242-270

Lau KM, Chan PH (1986) Aspects of the 40-50 day oscillation during the northern summer as inferred from outgoing longwave radiation. Mon Weather Rev 114:1354-1367

Leloup J, Lachkar Z, Boulanger JP, Thiria S (2007) Detecting decadal changes in ENSO using neural networks. Clim Dyn 28:147-162

Leloup J, Lengaigne M, Boulanger J-P (2008) Twentieth century ENSO characteristics in the IPCC database. Clim Dyn 30:277-291

Li ZX, Treut HL (1999) Transient behavior of the meridional moisture transport across South America and its relation to atmospheric circulation patterns. Geoph Res Lett 26(10): 1409-1412

Liebmann B, Smith CA (1996) Description of a complete (interpolated) outgoing longwave radiation dataset. Bull Am Meteorol Soc 77:1275-1277

Liebmann B, Kiladis GN, Marengo JA, Ambrizzi T, Glick JD (1999) Submonthly convective variability over South America and the South Atlantic convergence zone. J Clim 12:1877-1891

Lupo AR, Nocera JJ, Bosart LF, Hoffman EG, Knight DJ (2001) South American cold surges: types, composites, and case studies. Mon Weather Rev 129(5):1021-1041

Marengo J (1983) Estudios Agroclimático de la zona de Genaro Herrera (Requena-Loreto) y climático en la selva baja norte del Perú. Tesis UNALM, Ing. Meteorólogo. Lima, 464 pp

Marengo J (1984) Estudio Sinóptico Climático de los Friajes (Friagens) en la Amazonía Peruana. Revista Forestal del Perú 12(1-2):55-80

Marengo J, Cornejo A, Satymurty P, Nobre C, Sea W (1997) Cold surges in tropical and extratropical South America: the strong event in June 1994. Mon Weather Rev 125:2759-2786

Marengo J et al (2010) Recent developments on the South American monsoon system. Int J Climatol. doi:10.1002/joc.2254
Mitchell TD, Jones PD (2005) An improved method of constructing a database of monthly climate observations and associated high-resolution grids. Int J Climatol 25:693-712. doi:10.1002/ joc. 1181

Montes de Oca I (1995) Geografía y clima de Bolivia (Geography and climate of Bolivia). Bull Inst Fr Etud Andines 24:357-368

Müller and Ambrizzi (2007) Teleconnection patterns and Rossby wave propagation associated to generalized frosts over southern South America. Clim Dyn 29:633-645. doi:10.1007/s00382007-0253-x

Müller GV, Nuñes MN, Selucci ME (2000) Relationship between ENSO cycles and frosts events within the Pampa Húmeda region. Int J Climatol 20:1619-1637

Müller GV, Compagnucci RH, Nuñez MN, Salles MA (2003) Surface circulation associated with frost in the wet Pampas. Int $\mathrm{J}$ Climatol 23:943-961

Myers VA (1964) A cold front invasion of southern Venezuela. Mon Weather Rev 92:513-521

Oliveira AS, Nobre CA (1986) Meridional penetration of frontal systems in South America and its relation to organized convection in the Amazon. Publication INPE-3407-PRE/676

Parmenter F (1976) A Southern Hemisphere cold front passage at the equator. Bull Am Meteorol Soc 57:1435-1440

Penalba OC, Bettolli ML, Vargas WM (2007) The impact of climate variability on soybean yields in Argentina. Multivariate regression. Meteorol Appl 14:3-14

Pezza AB, Ambrizzi T (2005) Dynamical conditions and synoptic tracks associated with different types of cold surge over tropical South America. Int J Climatol 25:215-241

Poveda G, Waylen P, Pulwarty R (2006) Annual and inter-annual variability of the present climate in northern South America and southern Mesoamerica. Palaeogeogr Palaeoclimatol Palaeoecol 234:3-27

Quispe N (2005) Condiciones sinópticas de la incursión de una masa de aire frío en Sudamérica y su impacto en los cultivos de la selva caso especifico: Verano de 1996 e Invierno de 2000. Tesis UNALM, Ing. Meteorólogo. Lima Peru, 134 pp

Quispe N (2010) Estructura dinámica de una baja fría. Rev Peruana Geo-Atmosférica 1:125-133

Richardson AJ, Risien C, Shillington FA (2003) Using self-organizing maps to identify patterns in satellite imagery. Progress Oceanogr 59(2-3):223-239, ISSN 0079-6611

Ronchail J (1989a) Advections Polaires en Bolivie: mise en évidence et caractérisation des effets climatiques. Hydrol Cont 4:49-56

Ronchail J (1989b) Climatological winter effects of southern advections in Bolivia and north-west Brazil (1973-1984). Paper read at third international conference on southern hemisphere meteorology and oceanography: [extended abstracts]: November 13-17, 1989, Buenos Aires, Argentina

Rusticucci M, Vargas W (1995) Synoptic situations related to spells of extreme temperatures over Argentina. Meteorol Appl 2:291-300

Satyamurty P, Nobre CA, Silva Dias PL (1998) Tropics-South America. In: Karoly DJ, Vincent DG (Org.) Meteorology and hydrology of the Southern Hemisphere. Meteorology Monograph, Boston vol 49, pp 119-139

Seluchi M, Marengo J (2000) Tropical-midlatitude exchange of air masses during summer and winter in South America: climatic aspects and examples of intense events. Int J Climatol 20:10-20

Seluchi M, Calbete N, Rozante J (2001) Análisis de un desarrollo ciclónico en la costa oriental de América del sur. Revista Brasilera de Meteorología 16:151-165

Seluchi M, Garreaud R, Saulo FA, Norte AC (2006) Influence of the Subtropical Andes on Baroclinic Disturbances: a Cold Front Case Study. Mon Weather Rev 134:3317-3335. doi:10.1175/ MWR3247.1 
Solman S, Menéndez C (2003) Weather regimes in the South American sector and neighbouring oceans during winter. Clim Dyn 21:91-104

Uppala SM et al (2005) The ERA-40 re-analysis. Quart J R Meteorol Soc 131:2961-3012

Vera CS, Vigliarolo PK (2000) A diagnostic study of cold-air outbreaks over South America. Mon Weather Rev 128:3-24
Vera C, Higgins W, Amador J, Ambrizzi T, Garreaud R, Gochin D, Gutzler D, Lettenmaier D, Marengo J, Mechoso C, NoguesPaegle J, Silva Diaz P-L, Zhang C (2006) Towards a unified view of the American monsoon system. J Clim 19:4977-5000

Wang H, Fu R (2004) Influence of cross-Andes flow on the South American low-level jet. J Clim 17:1247-1262 